\title{
TENUN GRINGSING TEKNIK PRODUKSI, MOTIF DAN MAKNA SIMBOLIK
}

\author{
Ni Ketut Sri Astati Sukawati \\ Jurusan Teknik Sipil, Fakultas Teknik, Universitas Mahasaraswati, Denpasar \\ Jl. Kamboja No.11A, Kreneng Denpasar, Bali 80233 \\ E-mail : sriastatisukawati@yahoo.com
}

\begin{abstract}
Abstrak - Latar belakang dari penelitian ini adalah bahwa Desa Tenganan Pagringsingan Karangasem Bali penghasil Tenun Ikat terbaik di Indonesia. Salah satu Tenun Ikat tersebut adalah Tenun Gringsing yang diproduksi oleh masyarakat di Desa Tenganan Pagringsingan, Kabupaten Karangasem Bali. Desa ini merupakan salah satu desa yang berpenghuni orang Bali Mula atau Bali Aga (Bali Asli) alias Bali yang bukan berasal dari Jawa ketika terjadinya ekspedisi Kerajaan Majapahit ke Bali.

Tenun merupakan proses perjalinan antara benang pakan dan benang lungsi. Benang lungsi (benang yang dikaitkan pada alat tenun) dan benang pakan (benang yang dikaitkan pada benang lungsi) yang kalau keduanya dikaitkan akan menghasilkan motif. Proses karya seni kerajinan yang sederhana inilah yang sekarang berkembang menjadi beberapa tekhnik dalam menenun tergantung dari kreatifitas manusianya masing - masing sehingga menghasilkan ciptaan - ciptaan motif tenun yang menarik. Dalam perkembangan tenun selanjutnya terlihat bahwa kain tenun yang dihasilkan bukan lagi sebagai bahan penutup tubuh melainkan kain tenun ini memiliki fungsi lebih dari penutup tubuh, misalnya kain tenun ini memiliki fungsi sebagai pakaian adat atau sebagai identitas daerah pembuatnya. Selain itu, kain tenun dapat dijadikan karya seni yang muncul sesuai dengan kehidupan masyarakat setempat.

Tenun gringsing ini menggambarkan tentang sistem keseimbangan yaitu tentang hubungan manusia dengan manusia, manusia dengan alam, dan manusia dengan Tuhan. Dewa indra yang selalu dipuja oleh masyarakat Tenganan Pagringsingan Karangasem Bali di hormati dengan sebuah ritus perang pandan, rasa sakit seolah sirna oleh gringsing yang selalu membalut tubuh. Gringsing dipercaya dapat terhindar dari penyakit.Lebih kompleks lagi gringsing adalah penolak mara bahaya.

Berdasarkan latar belakang di atas maka dalam penelitian ini di fokuskan pada proses, bentuk motif dan makna simbolik tenun gringsing di Desa Tenganan Pagringsingan Karangasem Bali.
\end{abstract}

Kata Kunci : Tenun Gringsing, Pagringsingan, Tenganan

Abstract - The background of this research is that Tenganan Pagringsingan Village, Karangasem Bali, produces the best Ikat Weaving in Indonesia. One of the Ikat Weaving is Gringsing Weaving produced by the community in Tenganan Pagringsingan Village, Karangasem Regency, Bali. This village is one of the villages inhabited by the people of Bali Mula or Bali Aga (Original Bali) alias Bali who were not from Java when the Majapahit Kingdom expedition to Bali.

Weaving is a process of weaving between weft and warp threads. Warp yarns (threads that are attached to the loom) and weft (threads that are linked to the warp threads) which, if both are linked, will produce motifs. This simple process of craft art is now developing into a number of techniques in weaving depending on the creativity of each human - each so as to produce creations of attractive weaving motifs. In the subsequent development of weaving, it can be seen that the woven cloth produced is no longer a body covering material but the woven fabric has more functions than the body covering, for example this woven cloth has a function as traditional clothing or as the identity of the maker area. In addition, woven fabric can be used as a work of art that appears in accordance with local community life.

This gringsing weaving describes the system of balance which is about the relationship between humans and humans, humans with nature, and humans with God. The god of the senses who are 
always worshiped by the Tenganan Pagringsingan people of Karangasem Bali are respected by a pandanus war rite, the pain seems to vanish by gringsing which always binds the body. Gringsing is believed to be able to avoid disease. Even more complex gringsing is a repellent of danger.

Based on the background above, in this study the focus is on the process, forms of motifs and symbolic meaning of weaving gringsing in Tenganan Pagringsingan Village, Karangasem, Bali.

Keywords : Weaving Gringsing, Pagringsingan, Tenganan

\section{PENDAHULUAN Latar Belakang}

Desa Tenganan Pagringsingan

Karangasem Bali penghasil Tenun Gringsing terbaik di Indonesia. Konon ceritanya Desa Tenganan Pagringsingan Karangasem Bali ini adalah suku Bali asli ketika masa pemerintahan Kerajaan Majapahit di Bali. Desa Tenganan merupakan salah satu desa yang berpenghuni orang Bali Mula atau Bali Aga (Bali Asli) alias Bali yang bukan berasal dari Jawa ketika ekspedisi Kerajaan Majapahit ke Bali. Saat Majapahit menguasai Bali, penduduk asli Bali berpindah ke beberapa wilayah di Bali, di antaranya ke Desa Tenganan, Bali Timur.

Tenun merupakan proses perjalinan antara benang pakan dan benang lungsi. Benang lungsi (benang yang dikaitkan pada alat tenun) dan benang pakan (benang yang dikaitkan pada benang lungsi) yang kalau keduanya dikaitkan akan menghasilkan motif. Proses karya seni kerajinan yang sederhana inilah yang sekarang berkembang menjadi beberapa tekhnik dalam menenun tergantung dari kreatifitas manusianya masing - masing sehingga menghasilkan ciptaan - ciptaan motif tenun yang menarik.

Dalam perkembangan tenun selanjutnya terlihat bahwa kain tenun yang dihasilkan bukan lagi sebagai bahan penutup tubuh melainkan kain tenun ini memiliki fungsi lebih dari penutup tubuh, misalnya kain tenun ini memiliki fungsi sebagai pakaian adat atau sebagai identitas daerah pembuatnya. Bahkan lebih dari itu, kain tenun itu dapat merupakan karya seni yang muncul sesuai dengan kehidupan masyarakat setempat. Selain kain tenun ini sebagai kain penutup tubuh ataupun kain ini sebagai pakaian adat kain tenun juga dapat menunjukan kelas sosial atau derajat dan martabat si pemakainya. Kain tersebut dapat menunjukan pesan khusus yang terselip di dalam motif dan warna yang terkandung pada kain tenun tersebut.

Di Bali yang terkenal dengan keberanekaragaman budaya serta identik dengan upacara - upacara keagamaan yang sangat sakral dan sangat melekat didalam diri masyarakatnya membuat kebudayaan ini akan berkelanjutan secara turun temurun. Suku Bali Aga juga memiliki aspek- aspek unik yang terkait dengan religius mereka. Kehidupan mereka merupakan sinkritisme antara Agama Hindu Budha dengan tradisi Bali. Tradisi budaya Bali yang masih kuat sampai sekarang ini kemungkinan besar disebabkan oleh kehidupannya yang berorientasi terhadap kehidupan religi dan budaya masyarakat. Hal ini tentu saja sangat baik untuk perkembangan seni dan budaya di Bali terutama di daerah yang masih sangat terjaga kebudayaan dan kesenian aslinya seperti di Desa Tenganan Pagringsingan. Membicarakan Bali yang mempunyai banyak potensi seni, selain kesenian masyarakat di Bali juga mempunyai karya seni yang unik, otentik, dan kini sangat langka yaitu kain tenun gringsing di Desa Tenganan Pagringsingan.

Tenun ini diyakini dapat menyembuhkan orang dan hewan yang sakit di karenakan masyarakat Desa Tenganan Pagringsingan pada khususnya dan masyarakat Bali pada umumnya ini meyakini bahwa bentuk-bentuk dan symbolsimbol yang ada pada tenun tersebut mempunyai kekuatan magic. Di dalam masyarakat Bali kata "gringsing" mempunyai makna yaitu "gering" yang artinya sakit dan "sing yang artinya tidak dengan begitu arti kata "gringsing" bisa di artikan tidak sakit atau terhindar dari wabah.

Kain gringsing ini terbilang sangat unik mulai dari proses pembuatan yang sangat alami sampai dengan bentuk motif serta warna yang dihasilkan mengandung makna-makna yang berhubungan dengan tubuh dan kehidupan 
manusia. Bahan untuk membuat kain ini semua menggunakan bahan alami yang di dapat dari Bali asli. Selain bahannya yang langka, proses pembuatanya pun memakan waktu yang cukup lama bisa dari dua generasi ke atas sampai dengan dua atau tiga generasi kebawah serta pembuatan motif kain tenun gringsing ini sangat rumit. Kain tenun gringsing yang diwariskan nenek moyang mereka secara turun temurun ini hingga sekarang tetap dilestarikan.

Menurut sejarah Tenganan dahulu salah satu desa yang terletak dekat Pantai Candi Dasa daerah Manggis Karangasem. Desa ini disebut desa paneges, dan penduduk paneges ini mempunyai hubungan dengan desa Teges daerah Bedah Ulu Gianyar. Lama-lama terjadi erosi air laut maka penduduk Desa Paneges ini pindah di pedalaman. Di mana pindah ke pedalaman ini disebut dengan "ngetengahan". kemudian mengalami proses asimilasi menjadi nama Tenganan. Mengenai nama "Pagringsingan" ini ada hubunganya dengan kain gringsing yang ada di Desa Tenganan itu sendiri.

\section{Rumusan Masalah}

Berdasarkan latar belakang di atas maka dalam penelitian ini difokuskan pada proses, bentuk motif dan makna simbolik tenun gringsing di Desa Tenganan Pagringsingan Karangasem Bali.

\section{Tujuan}

Berdasarkan fokus masalah tersebut diatas maka tujuan yang hendak dicapai dalam penelitian ini adalah:

1. Mendeskripsikan proses pembuatan tenun gringsing di desa Tenganan Pagringsingan Karangasem Bali.

2. Mendeskripsikan bentuk motif dan makna simbolik tenun gringsing di DesaTenganan Pagringsingan Karangasem Bali.

3. Mendiskripsikan konstruksi masyarakat Desa Tenganan Pagringsingan Karangasem Bali.

\section{Manfaat}

Hasil penelitian ini diharapkan dapat berguna dan bermanfaat bagi masyarakat
Tenganan Pagringsingan Karangasem Bali untuk dijadikan referensi dan membawa wawasan seni budaya tenun tradisional masyarakat Tenganan Pagringsingan Karangasem Bali kepada masyarakat luas.

\section{PEMBAHASAN}

\section{Lokasi dan Keadaan Alam}

Kabupaten Karangasem terletak pada $8^{\circ} 00^{\prime \prime} 00^{\prime \prime}$ - 8 $8^{\circ} 41^{\prime \prime} 37,8^{\prime \prime}$ lintang selatan dan $115^{\circ} 35^{\prime \prime} 9,8-115^{\circ} 54^{\prime \prime} 8,9$ bujur timur. Letaknya di bagian timur pulau Bali dengan batas-batas wilayah sebagai berikut:

1. Sebelah timur berbatasan dengan SelatLombok

2. Sebelah barat berbatasan dengan Klungkung, Bali dan Buleleng

3. Sebelah selatan berbatasan dengan Samudra Indonesia

4. Sebelah utara berbatasan dengan Laut Jawa

Secara administratif pemerintah, Kabupaten Karangasem terbagi menjadi delapan kecamatan, enam puluh desa dan tiga kelurahan dengan luas wilayah keseluruhan 839,54 km (Badan Pusat Statistik Karangasem 1998: 1-2). Delapan kecamatan itu antara lain Kecamatan Karangasem, Bebendem, Selat, Sidemen, Rending, Manggis, Abang, dan Kecamatan Kubu. Desa Tenganan Pagringsingan yang menjadi lokasi penelitian ini termasuk salah satu dari Sembilan desa di Kecamatan Magis, Kabupaten Karangasem, tepatnya disebelah barat pusat pemerintahan kabupaten.

Jika dari ibu kota propinsi I (Denpasar) menuju arah timur dengan jarak kurang lebih 65 $\mathrm{km}$ dapat di tempuh dengan waktu kurang lebih dua jam. Sedangkan dari ibu kota kabupaten (Amlapura) berjarak sekitar $16 \mathrm{~km}$ dengan waktu tempuh satu jam, jika dari ibukota kecamatan jaraknya sekitar 8 kilo meter di tempuh dengan waktu kurang lebih tiga puluh menit. Desa ini berada pada ketinggian kurang lebih tujuh puluh meter diatas permukaan air laut.

Lokasi desa Tenganan Pagringsingan terletak di antara perbukitan yaitu bukit kangin di sebelah timur dan bukit kauh di sebelah barat. Batas-batas wilayah adalah dibatasi oleh 
beberapa desa yaitu:

1. Sebelah utara berbatasan dengan Kecamatan Bebandem

2. Sebelah timur berbatasan dengan Kecamatan Karangasem

3. Sebelah barat berbatasan dengan Desa Ngis

4. Sebelah selatan berbatasan dengan Nyuh Tebel dan Desa Pesedahan

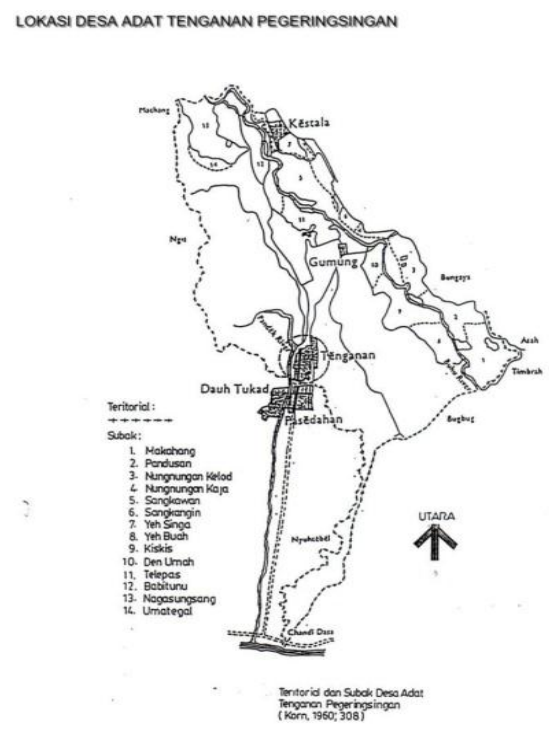

Gambar 2.2. Peta Kabupaten Karangasem

Mata Pencaharian Masyarakat Desa Tenganan Pagringsingan

Jika dilihat dari mata pencarian penduduk desa Tenganan Pagringsingan ini secara mayoritas adalah bertani dan berkebun. Hal ini dilihat dari tata guna tanahnya untuk lahan tegalan dan tanan sawah serta perkebunan. Tanah tegal dan perkebunan berlokasi di kawasan perbukitan barat, timur, utara desa. Sedangkan tanah sawah berlokasi disebelah timur bukit timur. Jenis tanah yang sebagian besar berbukit-bukit yang merupakan hutan desa dengan keadaannya yang cukup potensial, selain menghasilkan buah-buah juga menghasilkan kapas, ijuk, kayu-kayuan dan air nira (tuak). Lingkungan alam perbukitan itu bagi masyarakan tenganan pagringsingan itu mempunyai nilai ekonomi, nilai sosial, dan nilai alamiah sehingga sangat dijaga kelestarianya. Disamping pertanian dan perkebunan, mata pencarian lain adalah perternakan serta jasa/perdagangan.

Setelah desa ini berkembang menjadi desa pariwisata, maka penduduknya mulai mempunyai mata pencaharian sampingan dan ini semakin meningkat serta berkembang dimana sebagian penduduknya mempunyai kegiatan potensial di bidang pariwisata seperti pengrajin barang seni, pelukis, penulis lontar, pemahat, dan kerajinan industri kain. Industri kerajinan kain terutama kain gringsing ini ternyata sangat diminati oleh masyarakat luas terutama turis mancanegara. Sehingga kain gringsing ini juga menjadi salah satu daya tarik wisata yang selanjutnya berakibat desa ini semakin terkenal, disamping oleh potensi budaya dan sektor pariwisata.

Walaupun kain gringsing sangat mahal akan tetapi tidak mengurungkan niat wisatawan untuk memilikinya. Kain gringsing tergolong mempunyai harga yang sangat istimewa untuk ukuran selembar kain tenun, dikarenakan kain tenun ini mempunyai daya tarik tersendiri dari proses pembuatannya yang sangat alami dan motif yang mempunyai arti penting dalam kehidupan kita sehari-hari serta warna-warna yang dipilih sesuai dengan ketentuan yang ditentukan oleh desa adat tersebut dan proses pembuatannya secara manual yang memerlukan waktu berbulan-bulan untuk selembar kain gringsing.

Dalam membuat kain gringsing membutuhkan ketekunan dan ketelitian dalam proses penenunnannya. $\mathrm{Di}$ samping berkembangnya sektor pariwisata di desa Tenganan Pagringsingan akan tetapi fisik lingkungan hidup desa ini mempunyai makna dan pengertian yang sangat luas menurut falsafah Hindu tri hita karana masih berlaku di lingkungan masyarakat tersebut dan merupakan hal yang sangat penting serta telah ditaati oleh masyarakat Tenganan Pagringsingan. Potensi yang dimiliki Desa Tenganan Pagringsingan yang ahirnya menjadi tempat pariwisata. Sektor ini berakar dari adat istiadat atau budaya yang dimiliki secara turun temurun masih dipertahankan dan terus dilaksanakan oleh masyarakat.

Perkembangan Desa Tenganan Pagringsingan ini juga didukung oleh sarana yang cukup memadai untuk kelancaran hubungan lalu lintas. Sarana yang dimaksud adalah jalan yang sudah diaspal, dan angkutan 
umum yang tersedia setiap hari. Adapun sarana penunjang lainya seperti televisi, telepon, komputer, internet dan sarana penunjang lainya. Melihat alat transportasi dan fasilitas umum yang dimiliki masyarakat Tenganan Pagringsingan tidak jauh beda dengan desa-desa lain yang ada di Bali pada umumnya. (S.Swarsi, dkk. 1996/1997: 34). Adapun mekanisme penjualan kerajinan yang ada di desa Tenganan Pagringsingan adalah bisa secara langsung, yaitu pengrajin, tengkulak, dan pengecer.

\section{Proses Pembuatan Tenun}

Kegiatan menenun dilakukan di rumah pada waktu senggang oleh wanita, namun alatalat yang digunakan dibuat oleh laki-laki. Dalam pembuatan kain tenun ini ada peraturan khusus yang menentukan kapan waktu yang baik untuk memulai menenun. Penentuan hari yang baik tersebut sudah ada aturanya dalam masyarakat Tenganan Pagringsingan. Hari baik dalam masyarakat tenganan disebut dengan hari ngebeteng yang datangnya setiap tiga hari sekali. Dalam membuat tenun gringsing masyarakat Tenganan mempunyai sebuah peraturan atau larangan yang harus dipatuhi saat hendak membuat tenun.

1. Menenun haruslah pada hari-hari yang baik karena tidak semua hari bisa digunakan untuk menenun. Hari yang dianggap bagus adalah hari yang tidak bertepatan dengan bulan. Penenunan hari baik sudah ada perhitunganya dalam masyarakat Tenganan Pagringsingan tersebut. Hari yang bagus untuk memulai menenun ini perhitunganya tidak menggunakan hari-hari konfensional, akan tetapi menggunakan hari atau penanggalan yang sudah ditentukan oleh masyarakat Tenganan Pagringsingan.

2. Menenun juga tidak boleh bertepatan dengan upacara-upacara adat masyarakat Tenganan Pagringsingan

Selain peraturan-peraturan yang harus ditaati saat akan membuat tenun yang tidak kalah pentingnya adalah alat dan bahan yang digunakan dalam proses menenun. Alat dan bahan yang digunakan untuk menenun dalam masyarakat Tenganan Pagringsingan masih sangat sederhana. Bahan yang digunakan berasal dari hasil alam yang ada di sekeliling daerah mereka. Akan tetapi stok benang dan pewarna alam yang digunakan mereka membelinya dari masyarakat Pulau Nusa Penida.

Alat tenun yang digunakan adalah hasil buatan sendiri. Alat tenun terpisah ini pada dasarnya terbuat dari kayu dan bambu. Dengan sifatnya yang terpisah ini bila alat tenun tidak sedang digunakan maka alat ini akan disimpan dengan cara ditumpuk menjadi satu dan dibungkus dengan kertas koran kemudian disimpan di atas rak. Jika akan dipakai alat tenun ini akan dirangkai kembali membentuk serangkaian alat tenun gendong.

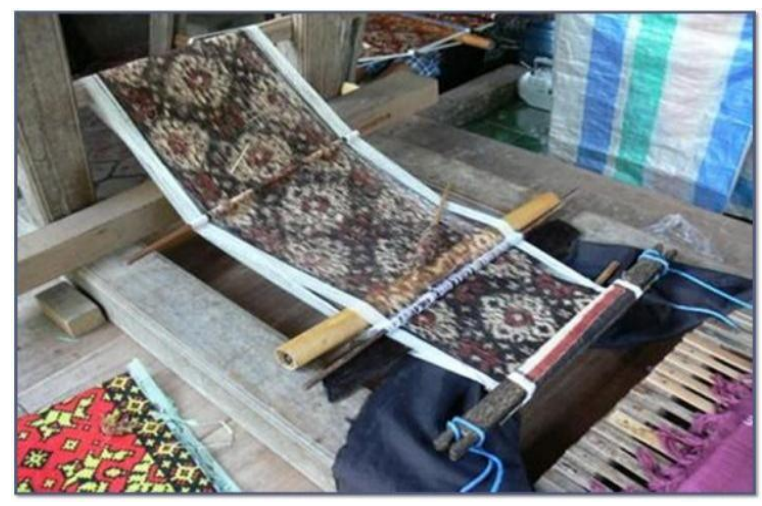

Gambar 2.3. Alat Tenun Gendongan yang sudah dirangkai

\section{Alat dan Bahan}

1. Alat

Alat tenun yang digunakan oleh masyarakat Tenganan Pagringsingan adalah alat tenun trdisional. Mesin tenun yang mereka buat bersifat "portable", sehingga dapat ditempatkan di mana saja sesuai dengan kebutuhan mereka. Mesin tenun ini masuk dalam kategori alat tenun gendongan yaitu alat tenun yang menggunakan tubuh si penenun untuk mengatur ketegangan benang lungsi. Ada beberapa alat yang digunakan dalam menenun oleh masyarakat Tenganan Pagringsingan antara lain adalah: 


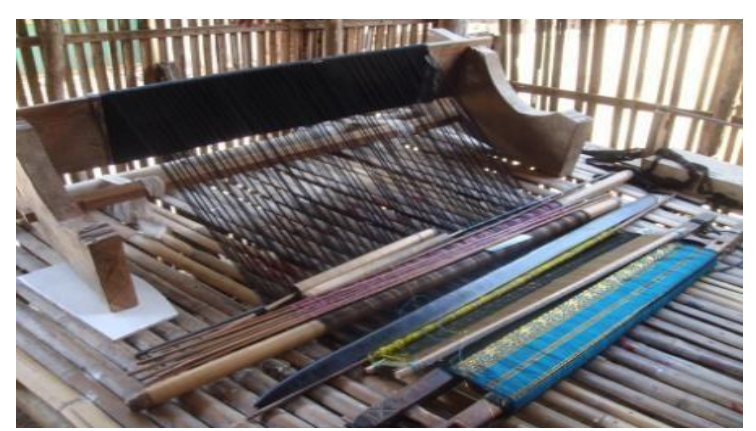

Gambar 2.4. Alat Tenun Gendongan

a. Papulayan adalah alat yang terbuat dari kayu yang pemakaianya diikatkan di pinggang dan bagian ujung kanan kirinya berbentuk melengkung untuk pegangan tali.

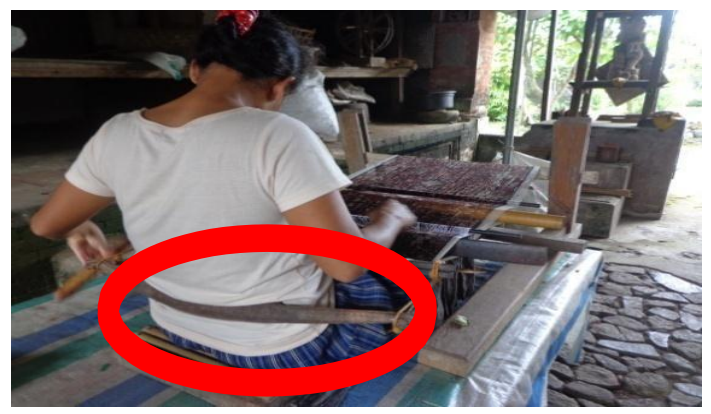

Gambar 2.5. Papulayan

b. Apitan terbuat dari bahan uyung merupakan penjepit pada bagian depan papulayan. Bentuknya pipih berukuran sekitar tiga centi meter dan panjangnya sesuai dengan lebar kain. Ujungnya diberi cagak untuk pegangan tali yang gunanya untuk menggulungkan

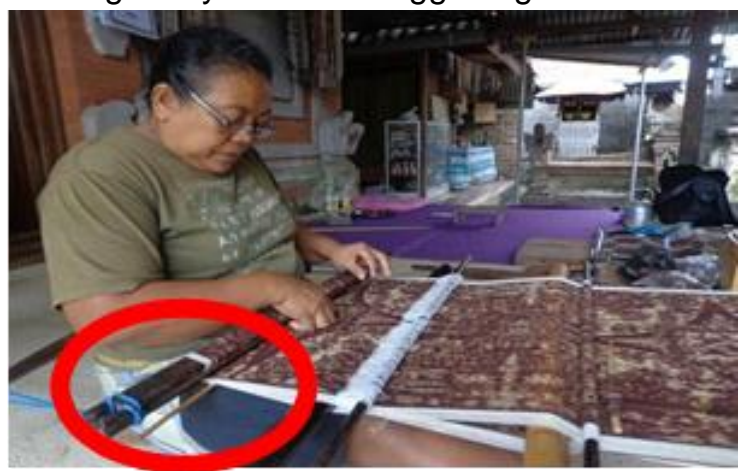

Gambar 2.6. Apitan

c. Tulek/sumpil yang terbuat dari pugpug (pelepah aren) yang bentuknya pipih sekitar $1,5 \mathrm{~cm}$ dan panjangnya juga di sesuaikan dengan lebar kain. Pada bagian ujungnya terdapat jarum diikat dengan benang yang nantinya dimasukan pada bagian pinggir kain yang telah jadi untuk meluruskan benang

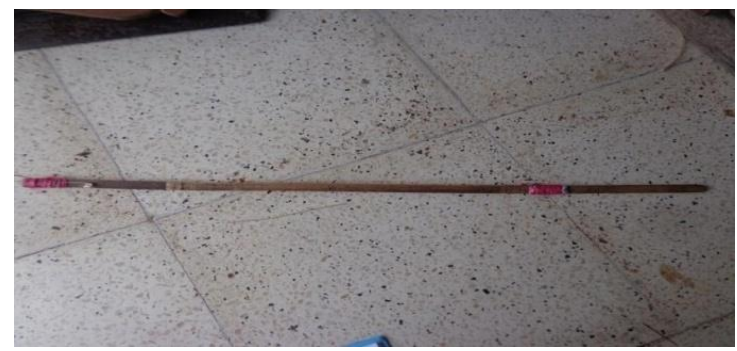

Gambar 2.7 Tulek

d. Belide terbuat dari bahan kayu aren (les celagi) bentuknya pipih lebarnya sekitar 4 $\mathrm{cm}$ dengan panjang sesuai lebar kain. Salah satu bagian ujungnya dibuat runcing agar lebih mudah memasukan dengan benang diki.

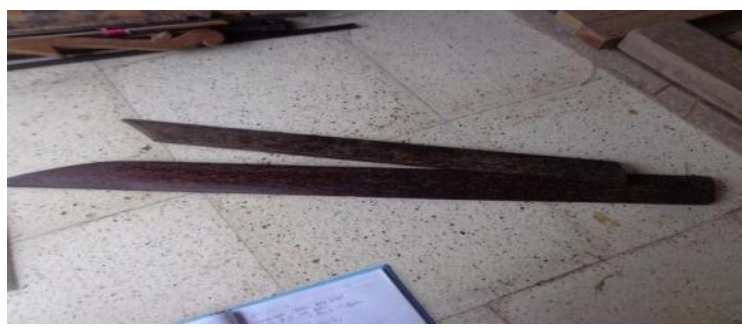

Gambar 2.8. Belide

e. Guhum terbuat dari tinjih (pohon pinang) yang bentuknya gilik (bulat panjang) dan ukuranya sebesar telunjuk. Alat ini berfungsi untuk mengangkat benang diki sehingga benang itu naik turun.

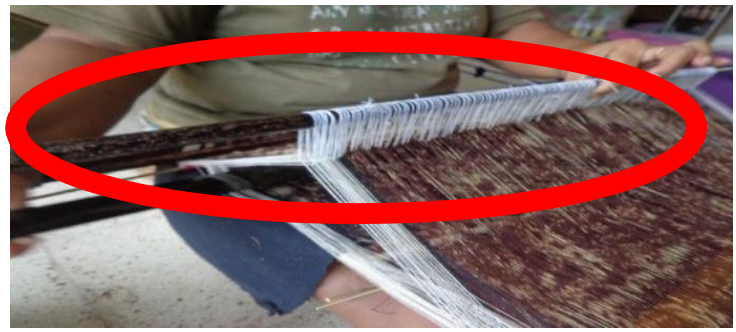

Gambar 2.9. Guhum

f. Pelumbungan alat ini terbuat dari bambu tamblang yang panjangnya disesuaikan dengan lebarnya kain gunanya untuk membuat lubang agar benang pakan 
bisa masuk. Benang ini dimasukan secara bolak balik sehingga menjadi susunan kain. Dalam pelumbungan tersebut diisi batu kecil sebagai pemberatnya.

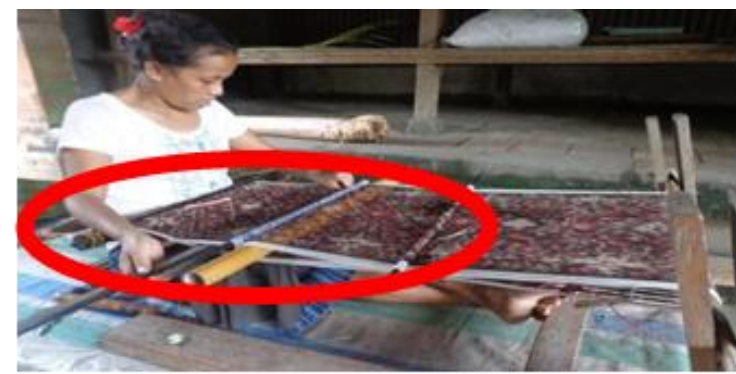

Gambar 2.10. Pelumbungan

g. Peleletan terbuat dari uyung (pohon aren) yang berbentuk gilik (bulatan panjang) sebesar telunjuk yang gunanya untuk meluruskan diki.

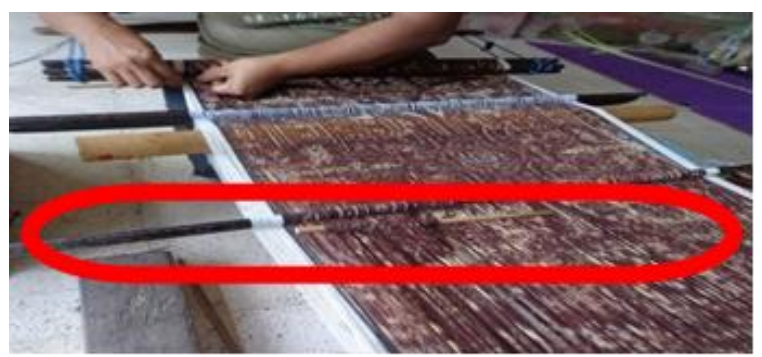

Gambar 2.11. Peleletan

h. Tagtag yang dibuat dari pupung (pelepah daun aren) yang gunanya sebagai pendalan dan menggulung benang diki (benang lungsi) pada bagian muka

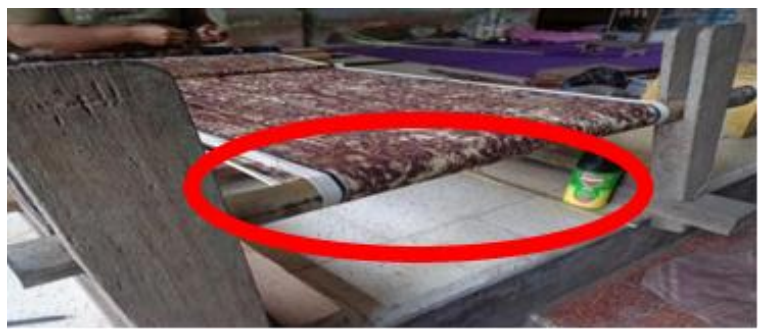

Gambar 2.12. Tagtag

i. Pengekean terbuat dari tulang kerbau, bentuknya pipih selebar $1,5 \mathrm{~cm}$ panjang kurang lebih $15 \mathrm{~cm}$ dan dipergunakan untuk mengorek-orek serta mengatur benang pakan dan benang diki sehingga akan membentuk ragam hias yang jelas.

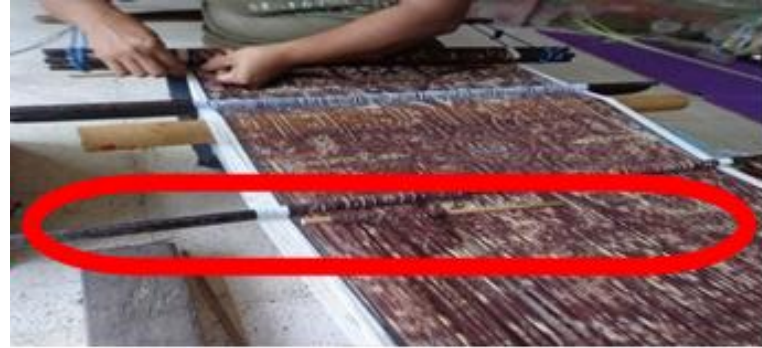

Gambar 2.13. Pengekean

j. Tundak terbuat dari bambu yang ujungnya dipotong pada ruas bambu sehingga tertutup bagian yang berlubang dan sedikit runcing. Kegunaanya sebagai tempat benang pakan yang telah digulung dengan pleting (suatu alat penggulung yang bentuknya sama dengan peleledan), tetapi bentuknya lebih kecil dan panjangnya hanya $15 \mathrm{~cm}$ sampai dengan $20 \mathrm{~cm}$.

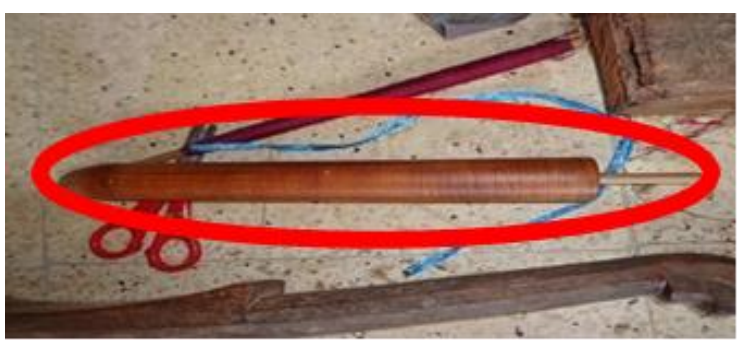

Gambar 2.14. Tundak

\section{Bahan}

Bahan yang digunakan untuk menenun pada masyarakat Tenganan Pagringsingan yaitu benang katun yang terbuat dari kapas. Akan tetapi bahan yang digunakan sebagai bahan utama menenun ini masih sangat terbatas maka dari itu mereka membeli bahan bakunya dari masyarakat Pulau Nusa Penida baik kapas dan bahan pewarnanya.

\section{Proses Produksi Tenun Gringsing}

a. Persiapan

Mempersiapkkan alat dan bahan yang akan digunakan dalam proses pembuatan tenun gringsing. Alat yang digunakan terdiri dari alat tenun tradisional dan alat penggilas kapas tradisional sedangkan bahan yang digunakan untuk menenun adalah 
benang katun yang terbuat dari kapas. Langkah selanjutnya adalah merangkai alat tenun karna alat tenun yang dipakai bersifat portebel atau terpisah-pisah. Proses selanjutnya adalah proses penggilasan kapas.

Pada proses penggilasan kapas alat yang digunakan bernama penggilas. Penggilas ini berfungsi untuk memisahkan kapas dan biji kapas. Alat penggilas ini penggunaanya masih sangat sederhana yaitu dengan cara diputar menggunakan tangan. Setelah kapas digilas kemudian kapas digulung gulung supaya mempermudah proses pemintalan.

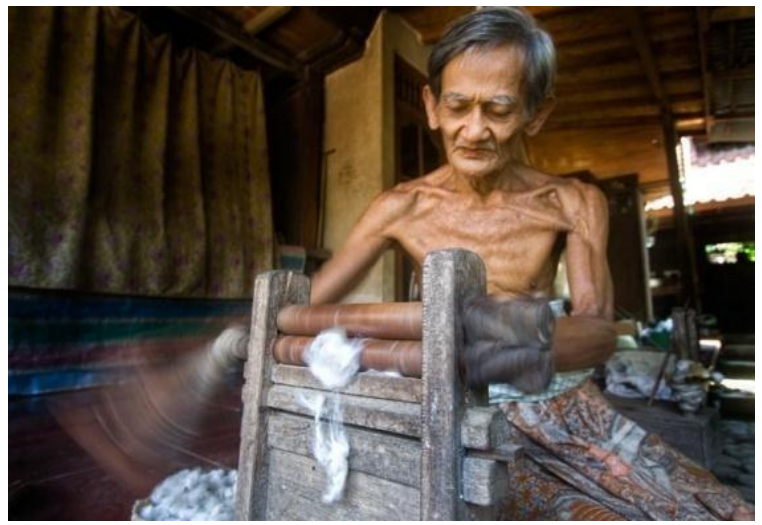

Gambar 2.15. Proses Penggilasan Kapas Menggunakan Alat Penggilas Kapas

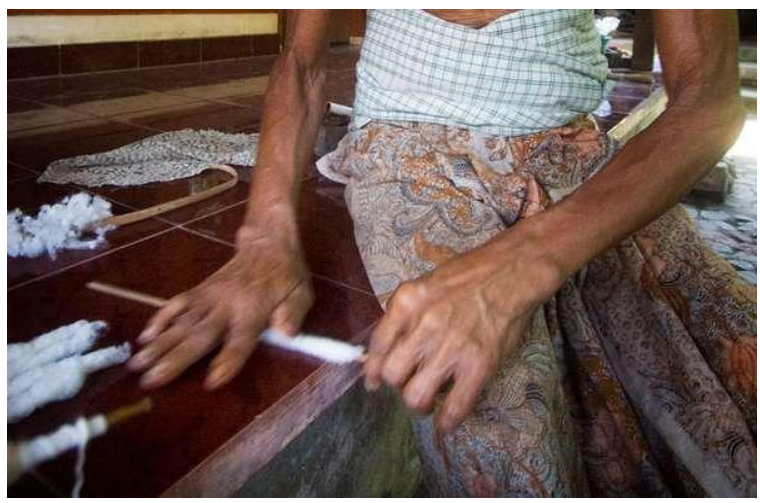

Gambar 2.16. Proses penggilasan kapas menggunakan tangan

b. Proses Pemintalan Benang

Dalam proses pemintalan benang alat yang digunakan berupa kincir yang terbuat dari kayu. Kincir berfungsi sebagai tempat penggulungan benang. Cara pemakaianya dengan cara diputar menggunakan tangan.

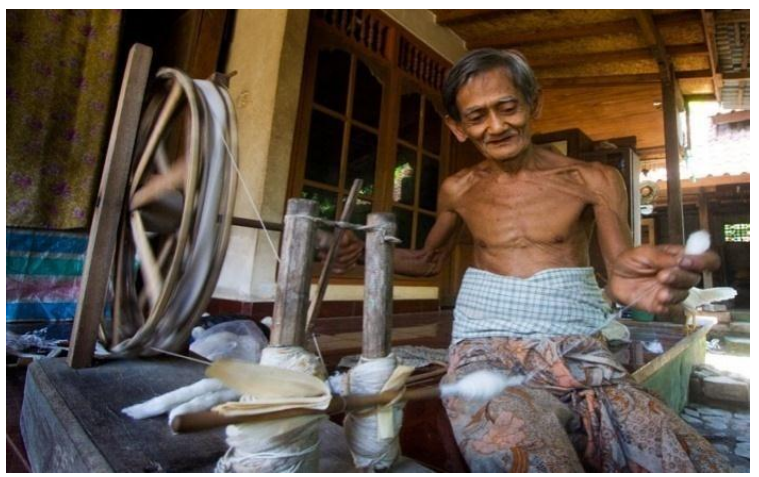

Gambar 2.17. Proses pemintalan benang

c. Proses Pewarnaan Benang yang Pertama

Setelah benang dipintal kemudian benang diwarna dengan minyak kemiri. Dalam pewarnaannya ini minyak kemiri dicampur dengan abu dapur dengan perbandingan 3:7 minyak kemiri 3 liter dan abu dapur 7 liter. Kemiri yang dipakai adalah kemiri yang sudah rusak dan tidak bisa dikonsumsi lagi dan sudah sangat lama supaya warna yang dihasilkan maksimal. Cara membuat warna dengan kemiri ini terlebih dahulu kemiri digilas kemudian kemiri di kukus dan dibungkus seperti bungkusan pepes kemudian digilas lagi hingga menghasilkan minyak. Setelah pembuatan minyak kemiri ini selesai kemudian benang mulai direndam ke dalam cairan minyak kemiri yang sudah dicampur dengan abu dapur selama kurang lebih 42 hari.

Pewarnaan benang ini harus bertepatan dengan hari baik yang sudah ditentukan masyarakat Tenganan. Setelah direndam kemudian benang diangin-anginkan pada batang bambu yang tergantung kemudian setiap tiga hari sekali benang dibolak balik supaya ketemu batang betengnya (hari baiknya) selama 42 hari sampai benang kering 
merata kemudian diangkat.

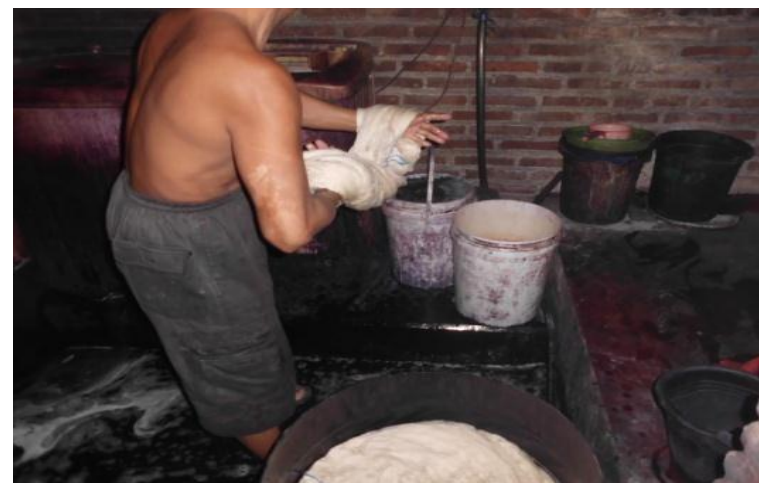

Gambar 2.18. Proses pewarnan benang

\section{Proses Pembuatan Tenun}

a. Menyusun Benang

Setelah benang yang diwarna tadi kering kemudian dilakukan penyusunan benang dengan cara dililitkan pada batang kayu yang berbentuk persegi yang pinggir atas dan bawahnya diikat dengan tali sehingga membentang.

Benang ini disusun menurut ukuran dan motif yang ingin dibuat. Benang dipisah-pisah menurut ukuran yang sudah ditentukan dan diikat pada bagian pinggir benang dengan tali raffia. Setelah proses pemisahan benang selesai kemudian benang benang tadi diberi motif atau penanda dengan cara digambarkan pada benang yang menbentang dan sudah dipisah pisa menjadi beberapa bagian. Kemudian mulai diikat menurut motif yang sudah ditentukan tadi dengan cara membagi menjadi tiga bagian.

Bagian benang yang akan di warna biru tua atau hitam diikat dengan tali raffia berwarna biru, bagian benang yang akan diwarna merah kemudian diikat dengan raffia berwarna merah, dan benang yang tetap berwarna putih diikat dengan raffia berwarna putih. Pengikatan ini berlaku pada benang lungsi dan benang pakannya.

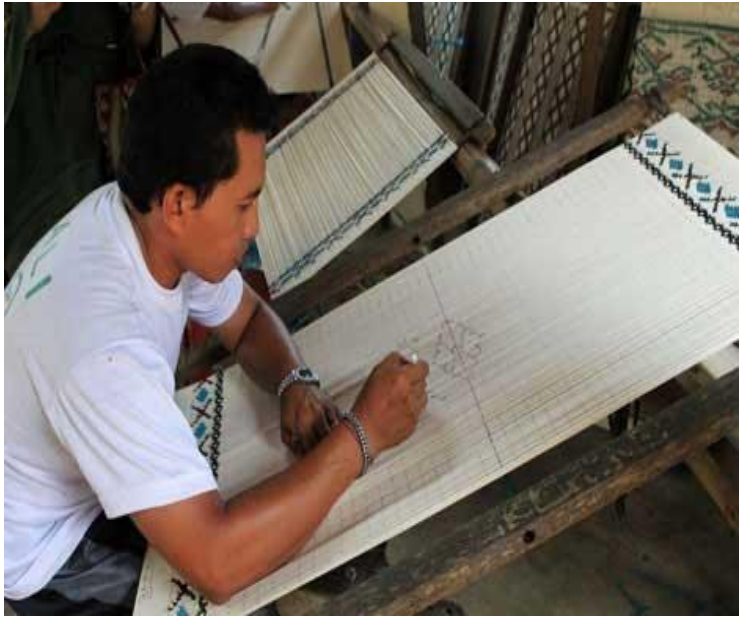

Gambar 2.19. Proses membuat pola motif dengan cara digambar menggunakan pensil

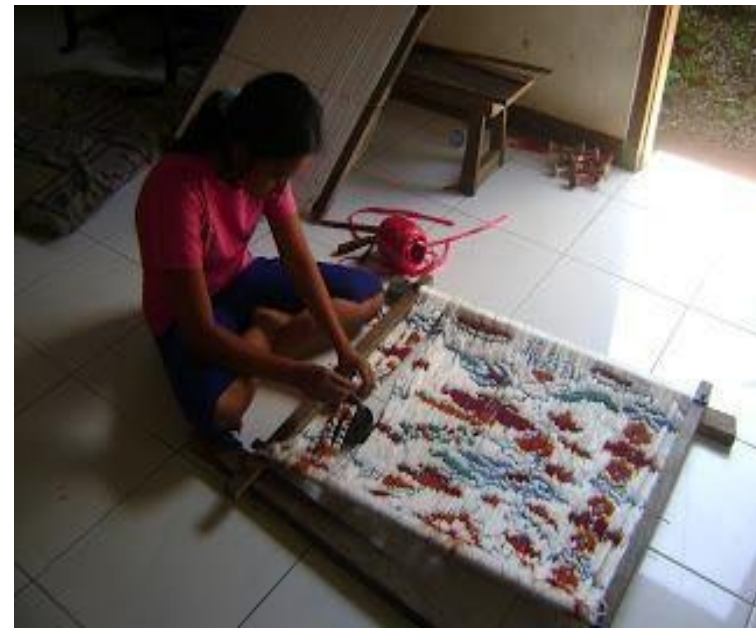

Gambar 2.20. Proses membuat motif dengan cara diikat

Setelah semua benang diikat sesuai dengan motif dan ukurang yang ditentukan kemudian benang dilepas dari papan kayu dan akan dilakukan pewarnaan tahap kedua yaitu pewarnaan dengan menggunakan daun indigofera. Cara pewarnaan ini pertama-tama daun indigofera yang sudah berbentuk bubuk diseduh dengan air sehingga menjadi cairan warna yang siap pakai. Kemudian benang yang sudah diikat dimasukan kedalam cairan warna tersebut selama kurang lebih 12 hari sampai 15 hari kemudian angkat dan keringkan seperti pada proses pewarnaan yang pertama tadi. Setelah kering kemudian ikatan yang berwarna merah tadi 
dibuka/dilepas.

Selanjutnya dilakukan pewarnaan yang ketiga atau pewarnaan yang terahir dengan menggunakan pewarna alam dari akar mengkudu. Akar mengkudu yang sudah menjadi serbuk kemudian diseduh dengan air sehingga menjadi pewarna yang siap pakai kemudian benang yang sudah dilepas ikatanya tadi direndam selama kurang lebih 15 hari. Dalam proses pewarnaan yang terahir ini di lakukan peletakan bunga dan sesajen serta doa doa khusus untuk persembahan kepada Dewa/Tuhan supaya warna yang dihasilkan maksimal.

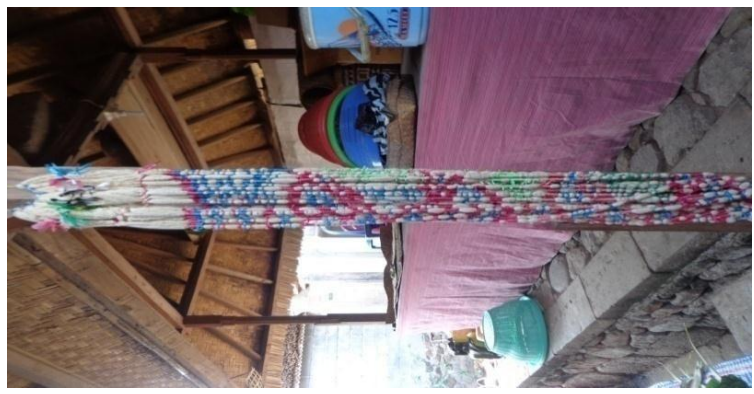

Gambar 2.21. Benang yang sudah diikat

Setelah proses pewarnaan selesai kemudian dilakukan pembagian motif yang disebut dengan nyaik. Kemudian proses selanjutnya benang ini diolesi dengan bubur beras supaya warna kain tetap awet. Setelah itu kain dibersihkan dengan air dan diangin-anginkan sampai kering.

b. Menghanai

Menyusun benang bermotif yang akan ditenun pada alat tenun gendongan sesuai dengan ukuran yang ditentukan. Mengkanai dilakukan dengan cara melilitkan benang pada tongkat kayu agar benang lebih mudah disusun.

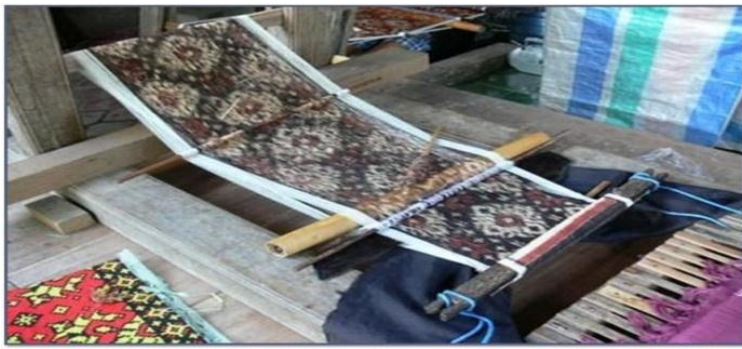

Gambar 2.22. Susunan benang yang sudah dihanai

\section{Memasukan Benang ke dalam Sisir}

Proses pemasukan benang yang akan ditenun ke dalam sisir memakan waktu seharian karena memasukan benang satu persatu seperti kita memasukan benang pada jarum jahit. Dibutuhkan ketelitian dan kesabaran dalam proses ini. Sisir yang dimaksud di sini bukan sisir seperti yang ada di ATBM. Proses ini sering disebut dengan nyucuk. Alat yang digunakan untuk nyucuk adalah bilahan kayu kecil yang ujungnya kecil dan runcing. Alat ini terbuat dari tulang kerbau dan bulu landak.

Setelah benang terpasang semua kemudian dapat dimulai proses penenunan. Kekencangan benang lungsi diatur oleh badan penenun. Selain dibantu oleh apitan dan togtogan benang pakan diletakan pada alat yang bernama teropong. Lama penenunan kain tergantung ukuran dan motif yang di buat.

\section{Menenun}

Menenun adalah proses membuat kain dengan cara menyilangkan benang lungsi dan benang pakan. Proses pembuatan kain dengan cara di tenun ini lebih lama dibandingkan dengan dengan proses yang lainya.

Untuk ukuran kain dengan lebar $25 \mathrm{~cm}$ dan panjang 2 meter bisa memakan waktu berbulan-bulan. Proses menenun dilakukan dengan cara tangan penenun terlebih dahulu mengangkat jajaran mata gun sehingga mulut lungsi terangkat kemudian dimasukan teropong di tengah-tengah benang lungsi yang terangkat.

Barerak juga berfungsi untuk mendorong dan merapatkan sisir sehingga benang pakan dapat tersusun dengan baik. 


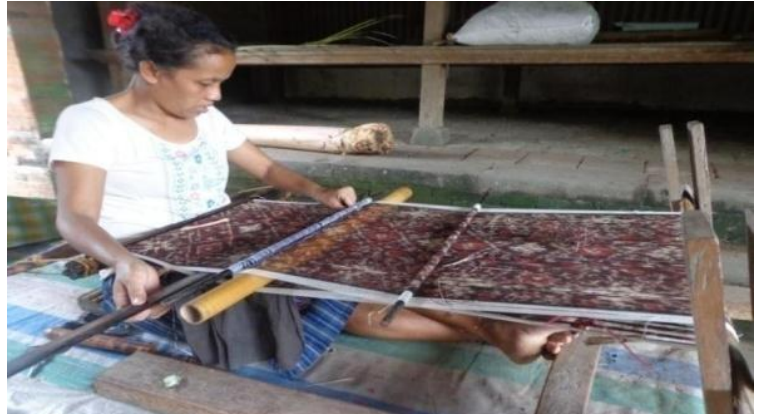

Gambar 2.23. Proses menenun

\section{Finhising}

Finhising ini adalah proses terahir dalam pembuatan tenun yaitu merapikan bagian bagian tenun yang sudah menjadi kain, seperti mengikat pada bagian ujung kain yang masih tersisa supaya tenun tidak mudah rusak.

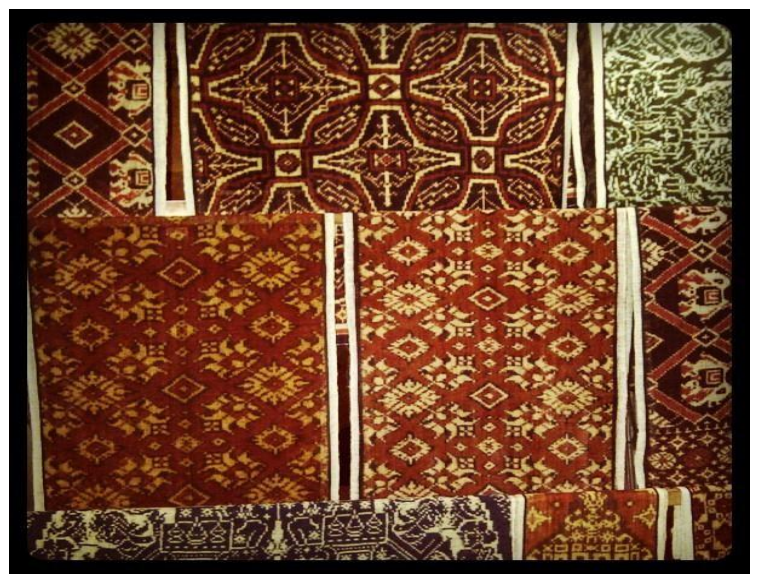

Gambar 2.24. Hasil tenun yang sudah jadi

Secara keseluruhan proses pembuatan tenun masyarakat Tenganan Pagringsingan tidaklah berbeda dengan proses pembuatan tenun tradisional daerah lain. Penggunaan alatalat sederhana (alat tenun gendongan). Alat tenun ini masih menggunakan tubuh penenunya sebagai pengatur tegangan benang lungsi. Bahan yang digunakan untuk membuat tenun gringsing ini adalah benang katun yang terbuat dari kapas. Masyarakat Tenganan Pagringsingan memenuhi kebutuhan sandangnya sendiri sebagai sarana prasarana dalam melakukan upacara adat maupun upacara keagamaan. Dalam proses pembuatan dari awal hingga menjadi selembar kain ini tidak ada perubahan sama sekali dari jaman dahulu nenek moyang hingga sekarang generasi penerusnya. Proses pembuatan yang sangat alamiyah dan sangat sederhana ini di pertahankan hingga saat ini. Dahulu kain ini dipergunakan hanya untuk kalangan masyarakat Tenganan pada khususnya dan masyarakat Bali pada umumnya sebagai kain sakral yang digunakan untuk sarana upacara keagamaan saja, namun saat ini tenun gringsing sudah menjadi nilai ekonomis yang bisa di perjual belikan secara luas untuk berbagai kepentingan.

\section{Bentuk dan Makna Simbolik Tenun Gringsing}

Tenun Gringsing merupakan tenun dobel ikat yang hanya dibuat di tiga negara yaitu Jepang, India, dan Indonesia yang terletak di Desa Tenganan Pagringsingan Karangasem Bali. Tenun Gringsing ini merupakan satu kesatuan yang sangat melekat dalam kehidupan masyarakat Tenganan Pagringsingan pada kususnya dan masyarakat Bali pada umumnya. Tenun gringsing ini mempunyai peranan penting dalam kehidupan masyarakatnya karena tenun ini menjadi hal yang wajib sebagai sarana prasarana pada saat dilakukanya upacara keagamaan maupun upacara adat. Adapun motif-motif tenun gringsing antara lain adalah:

\section{Motif Lubeng}

Selembar kain tenun yang mempunyai motif menyerupai bintang di langit, berwarna merah, hitam, dan putih, serta didampingi dengan motif kalajengking yang menyimbulkan empat arah mata angin yang dijaga oleh kalajengking. Motif ini adalah motif yang menjadi dasar lambang atau simbol desa Tenganan Pagringsingan. Motif ini mempunyai makna yaitu bahwa di Desa Tenganan Pagringsingan ini ada empat pintu masuk dari segala arah. Kepercayaan orang Desa Tenganan Pagringsingan sendiri tentang motif ini adalah jika sesuatu yang buruk datang dari arah Timur maka akan hilang ke arah Barat dan sebaliknya. 


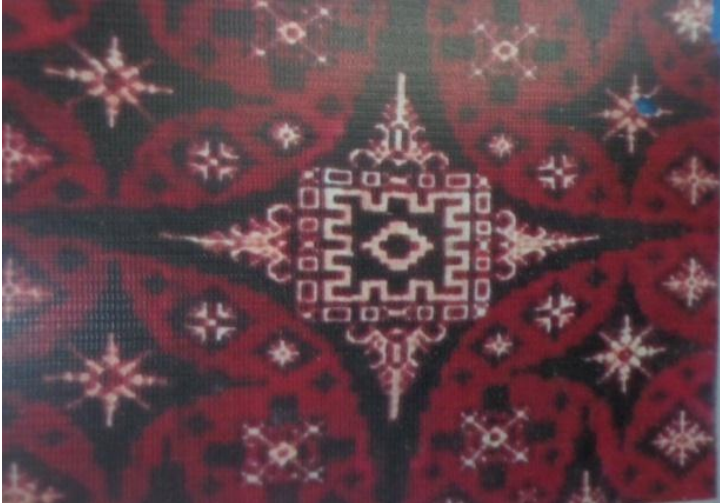

Gambar 2.25. Motif Tenun Gringsing Lubeng

Gambar pecahan bentuk motif tenun Gringsing Lubeng

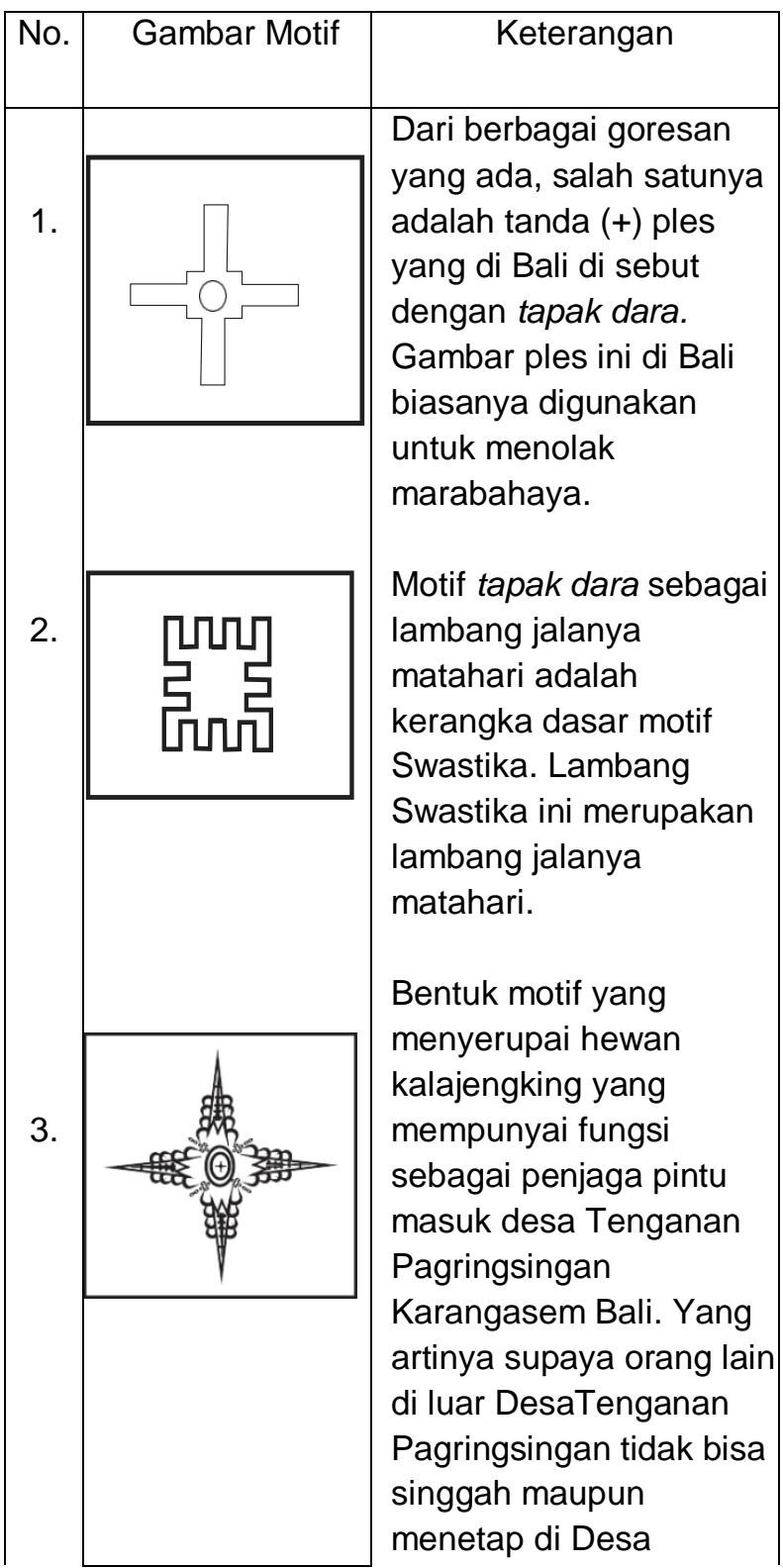

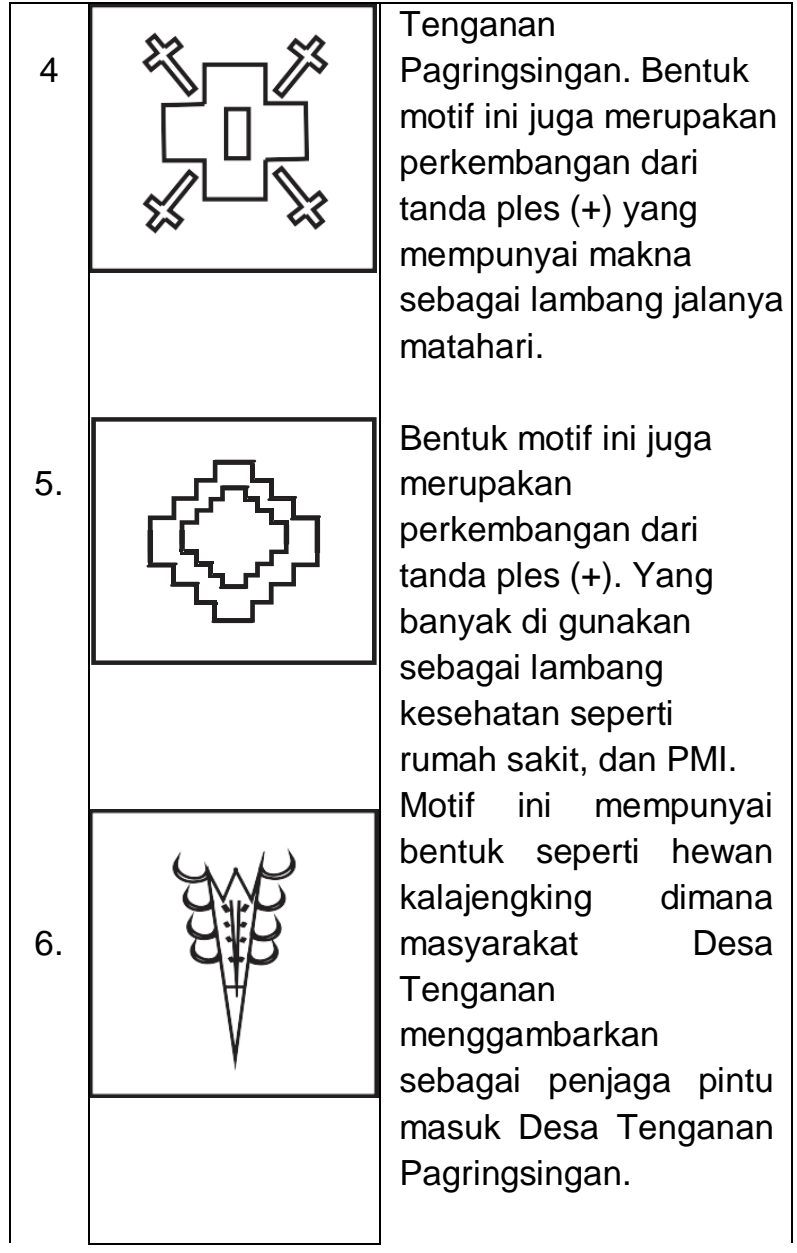

2. Motif Cecempaka

Motif Cecempaka dicirikan dengan bentuk bunga cempaka dan berfungsi sebagai pakaian adat dan upacara keagamaan.

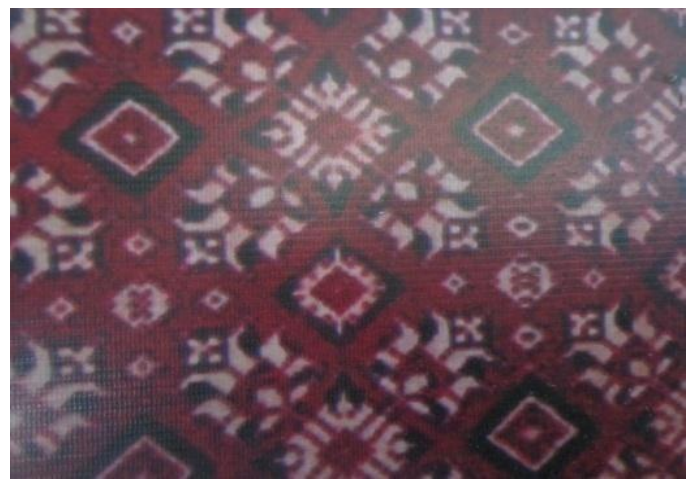

Gambar 2.26 Motif Tenun Gringsing Cecempaka

Gambar pecahan motif kain Gringsing Cecempaka 


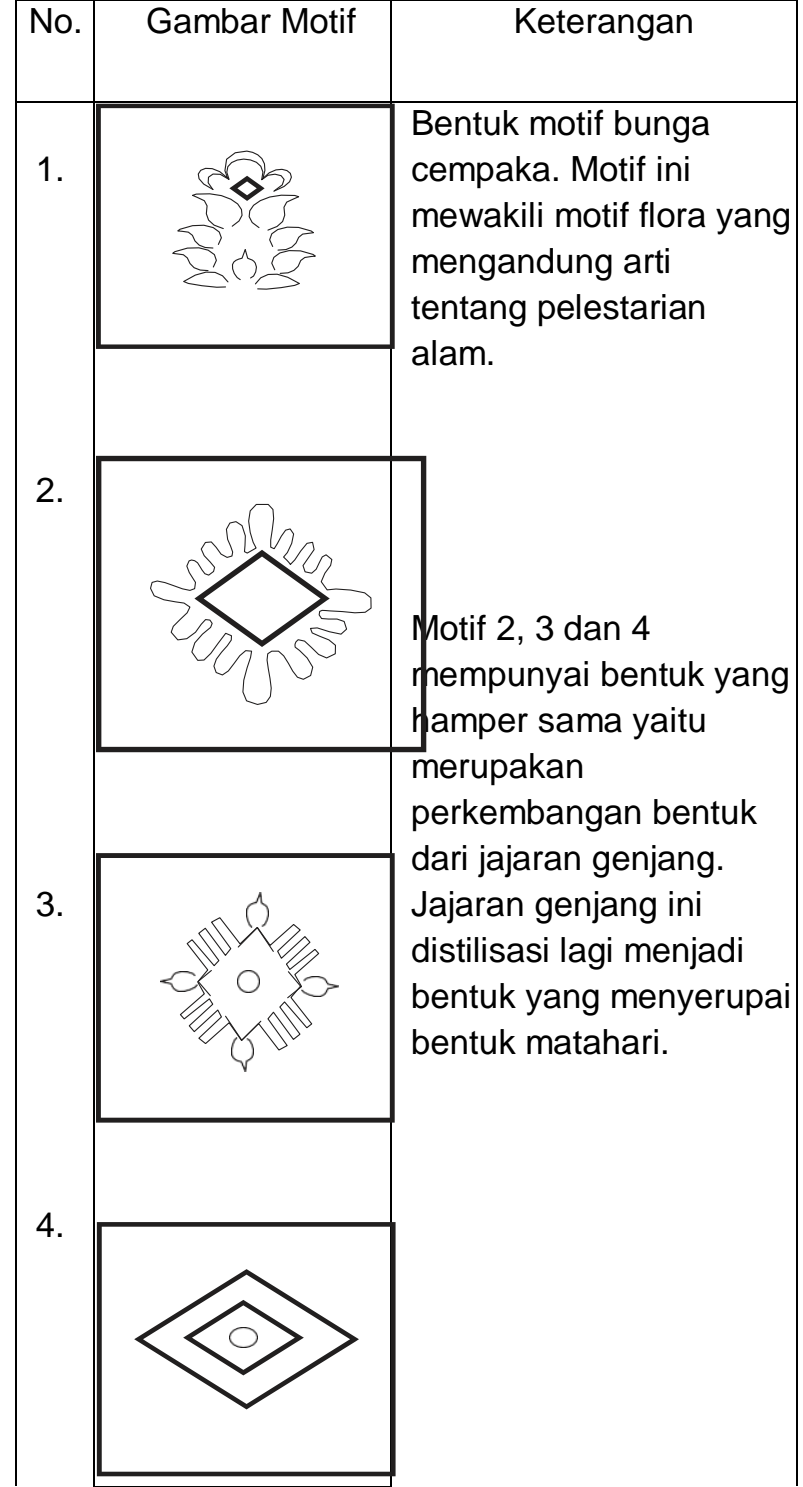

3. Wayang Putri

Kain Gringsing Wayang terdiri dari kain Gringsing Wayang Kebo dan Kain Gringsing Wayang Putri. Motif ini paling sulit dikerjakan dan memerlukan waktu pembuatan hingga lima tahun. Motif wayang hanya terdiri dari dua warna, yaitu hitam dan putih. Untuk menciptakan garis putih yang membentuk wayang di perlukan ketelitian tinggi karena tingkat kesulitan selama proses pengikatan dan penenunan kain relatif sulit. Wayang Kebo memiliki motif wayang laki-laki dan Wayang Putri memiliki motif Wayang Putri.

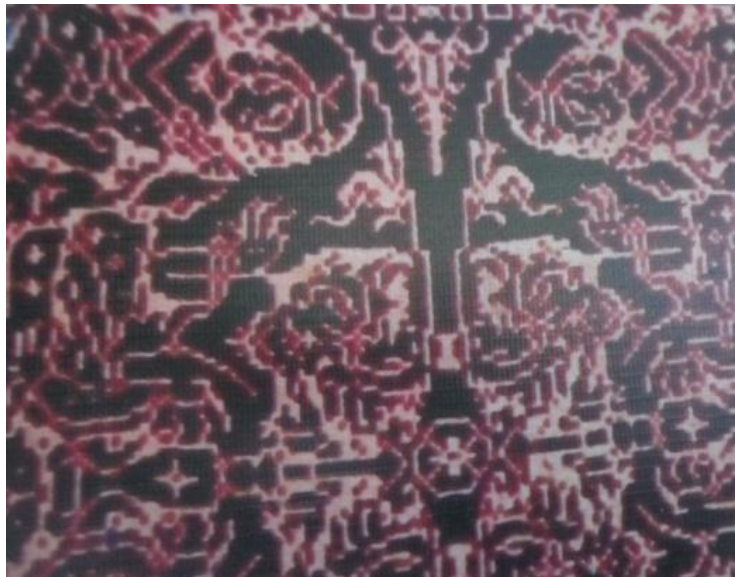

Gambar 2.27. Motif Kain Tenun Gringsing Wayang Putri

Gambar pecahan kain Tenun Gringsing Wayang Putri

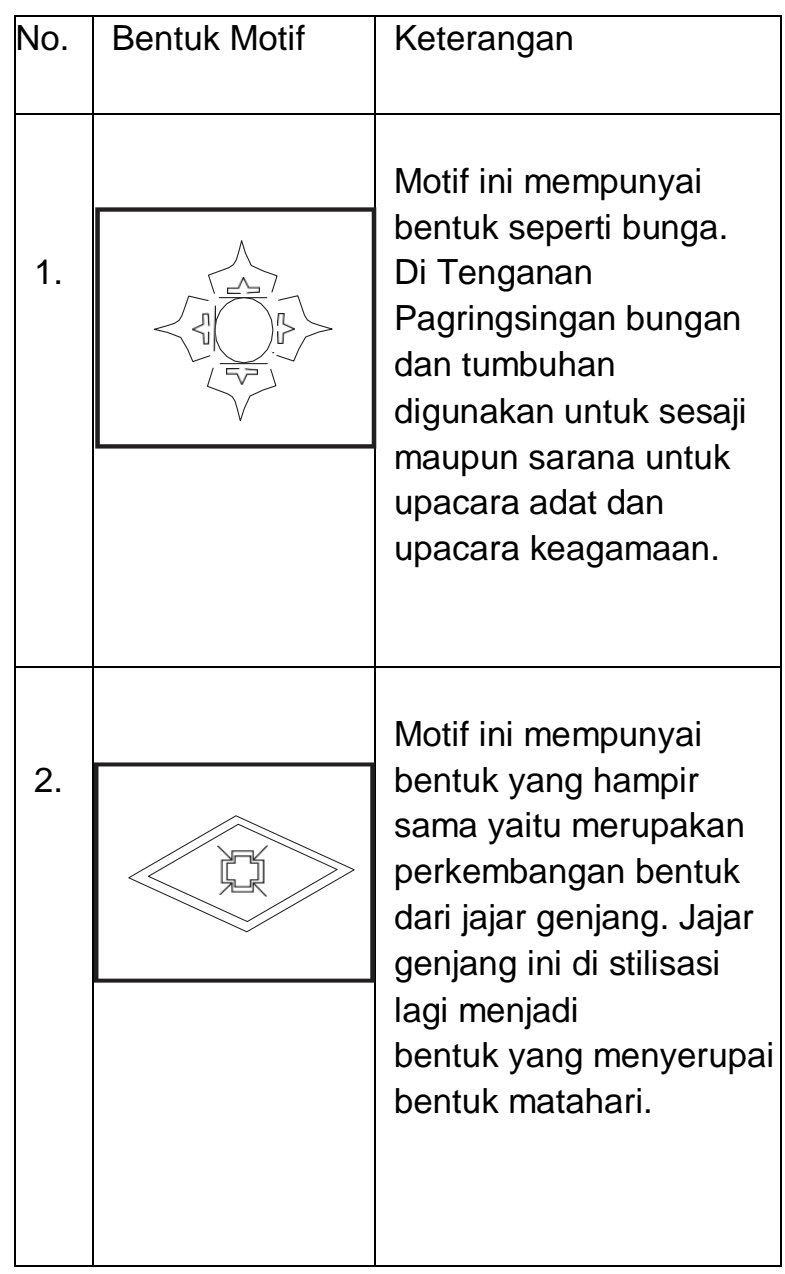




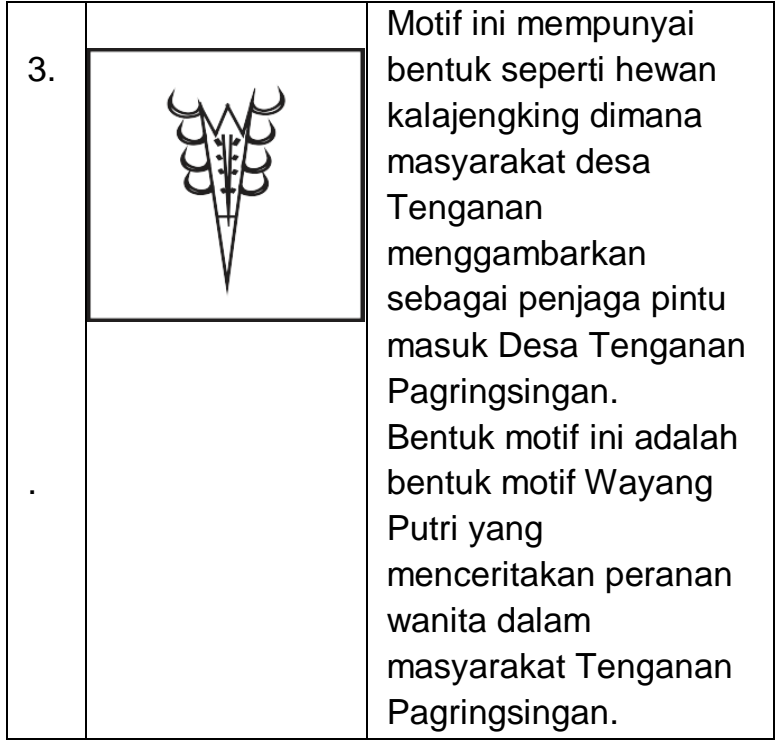

4. Wayang Kebo

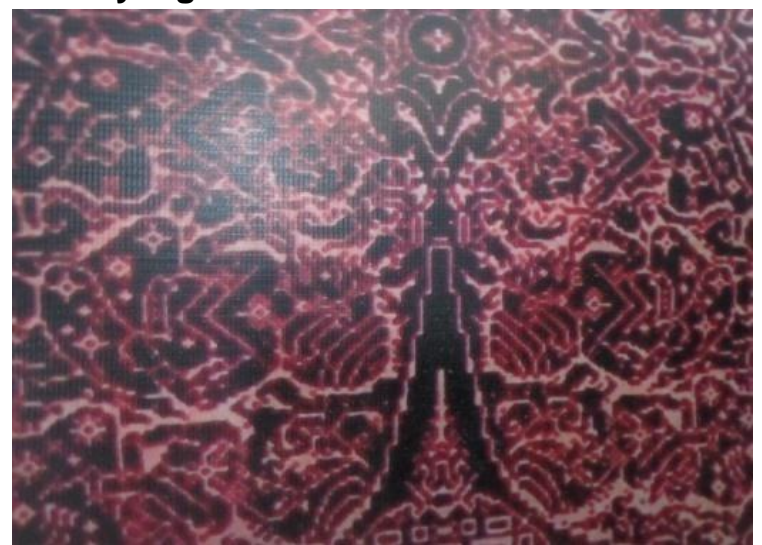

Gambar 2.28. Pecahan Kain Gringsing Wayang Kebo

Gambar pecahan kain Tenun Gringsing Wayang Kebo

\begin{tabular}{|l|c|l|}
\hline No. & Gambar Motif & \multicolumn{1}{c|}{ Keterangan } \\
\hline & $\begin{array}{l}\text { Motif ini mempunyai } \\
\text { bentuk seperti bunga. Di } \\
\text { Tenganan } \\
\text { Pagringsingan bunga } \\
\text { dan tumbuhan } \\
\text { Digunakan untuk sesaji } \\
\text { maupun sarana untu } \\
\text { upacara adat dan } \\
\text { upacara keagamaan. }\end{array}$ \\
\hline
\end{tabular}

2.

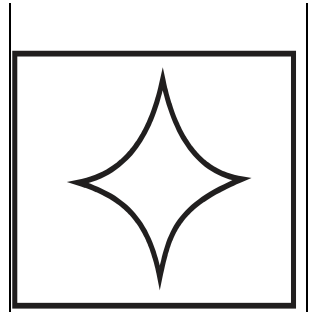

3.

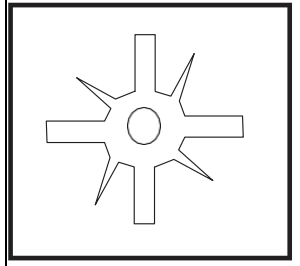

Dari berbagai goresan yang ada, salah satunya adalah tanda $(+)$ ples yang di Bali disebut dengan tapak dara. Gambar ples ini di Bali biasanya digunakan untuk menolak marabahaya.

Motif ini mempunyai bentuk seperti hewan kalajengking dimana masyarakat Desa Tenganan menggambarkan sebagai penjaga pintu masuk Desa Tenganan Pagringsingan.

\section{Cemplong}

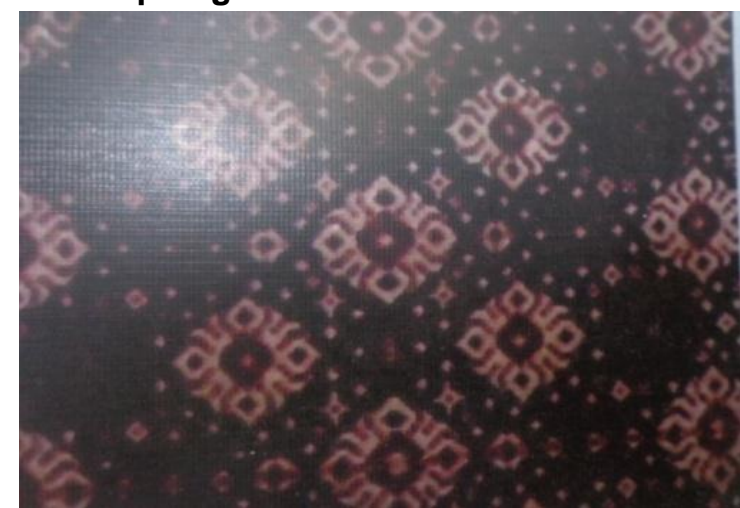

Gambar 2.29. Bentuk Motif Tenun Gringsing Cemplong

Gambar pecahan motif Tenun Gringsing Cemplong 


\begin{tabular}{|l|l|}
\hline No. & \multicolumn{1}{|c|}{ Keterangan } \\
\hline Motif ini mempunyai \\
bentuk seperti bunga. \\
Yang dalam \\
masyarakat Tenganan \\
Pagringsingan bunga \\
adalah salah satu \\
sarana prasarana untuk \\
upacara adat dan \\
upacara keagamaan.
\end{tabular}

\section{Patlikur isi}

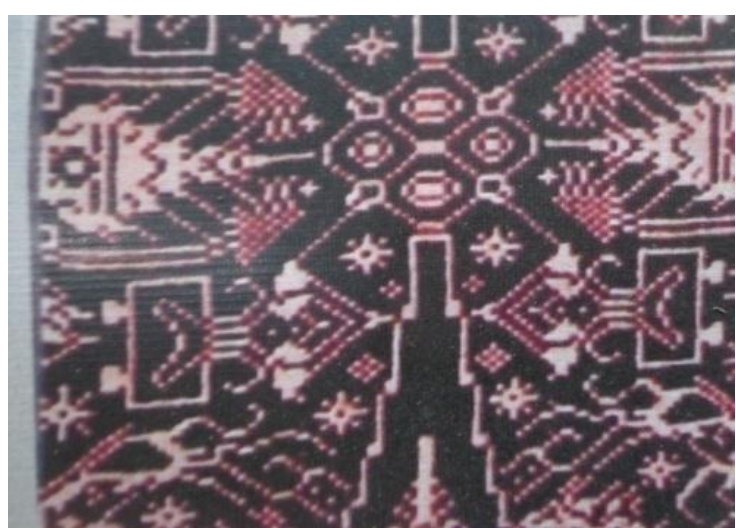

Gambar 2.30. Bentuk Motif Tenun Gringsing Patlikur Isi
Pecahan motif Tenun Gringsing Patlikur Isi

\begin{tabular}{|c|c|c|}
\hline No. & Gambar Motif & Keterangan \\
\hline 1 & & $\begin{array}{l}\text { Motif ini merupakan } \\
\text { perkembangan dari } \\
\text { bentuk tanda(+) ples } \\
\text { yang di Bali disebut } \\
\text { dengan tapak dara. } \\
\text { Gambar ples ini di Bali } \\
\text { biasanya digunakan } \\
\text { untuk menolak } \\
\text { marabahaya. Bentuk } \\
\text { bulat di tengah diartikan } \\
\text { sebagai sumbu } \\
\text { perputaran alam } \\
\text { semesta. Motif ini } \\
\text { mempunyai bentuk } \\
\text { seperti pura (tempat } \\
\text { ibadah) umat Hindhu. } \\
\text { Motif yang digambarkan } \\
\text { dalam kain Gringsing ini } \\
\text { melambangkan } \\
\text { bagaimana masyarakat } \\
\text { Tenganan Pagringsingan } \\
\text { melakukan ritual } \\
\text { Keagamaan. } \\
\text { Motif ini mempunyai } \\
\text { bentuk seperti rumah } \\
\text { tawon yang bermakna } \\
\text { keberaturan suatu bentuk } \\
\text { masyarakat. }\end{array}$ \\
\hline
\end{tabular}

\section{Tali Dandan}

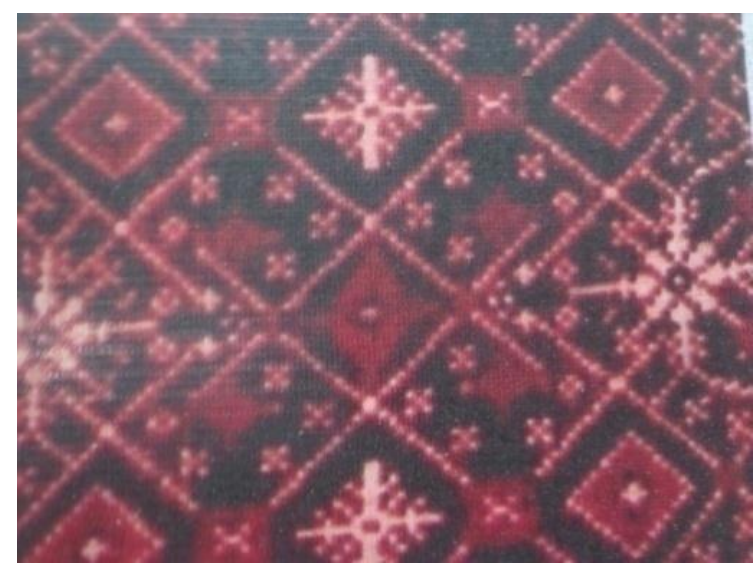

Gambar 2.31. Motif Tenun Gringsing Tali Dandan 
Gambar pecahan motif Tenun Gringsing Tali Dandan

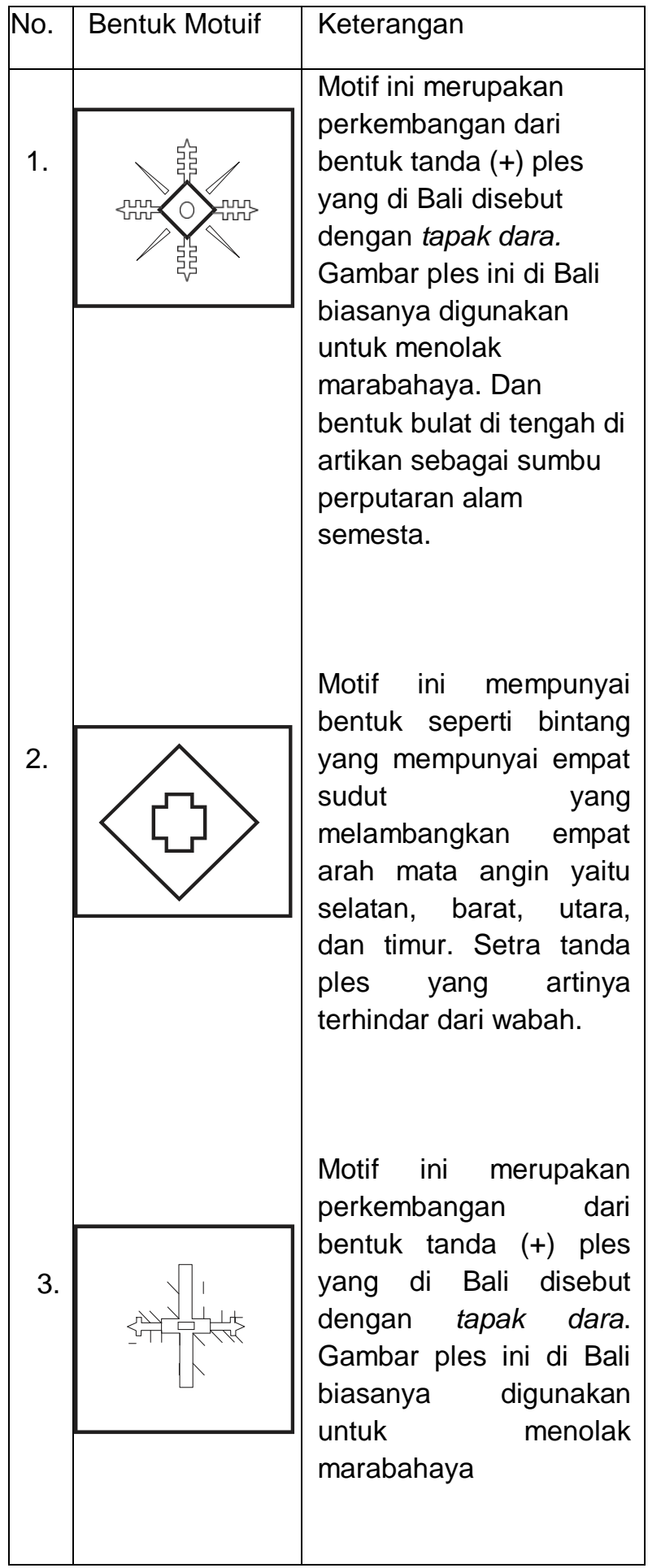

\section{Batung Tuung}

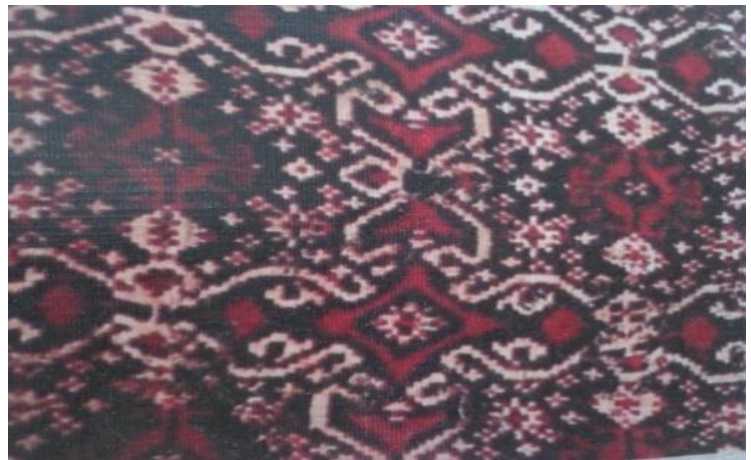

Gambar 2.32. Motif Tenun Gringsing Batung Tuung

Gambar pecahan motif Tenun Gringsing Batung Tuung

\begin{tabular}{|l|l|l|}
\hline No & \multicolumn{1}{c|}{ Keterangan } \\
\hline Motif ini mempunyai \\
bentuk seperti \\
mankota bunga. \\
Yang dalam \\
masyarakat \\
Tenganan \\
Pagringsingan, \\
bunga adalah salah \\
satu sarana \\
prasarana untuk \\
upacara adat dan \\
upacara keagamaan.
\end{tabular}




\section{Enjekan Siap}

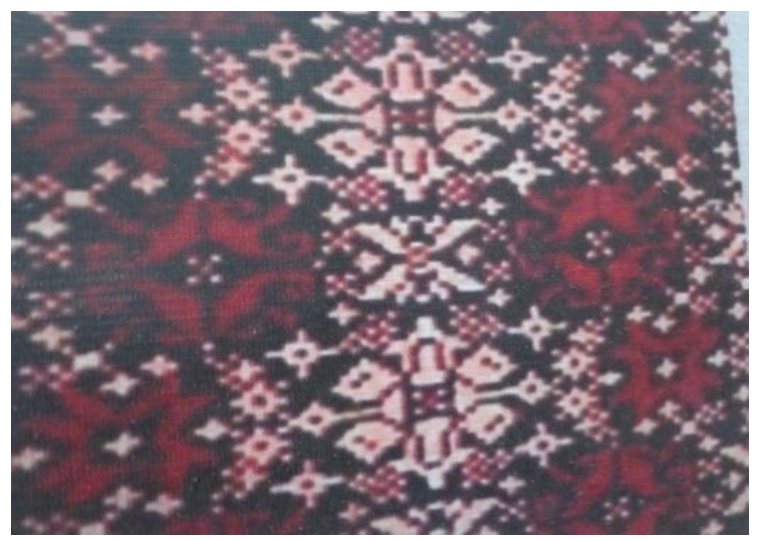

Gambar 2.33. Motif Kain Gringsing Enjekan Siap

Gambar pecahan motif Kain Gringsing Enjekan Siap

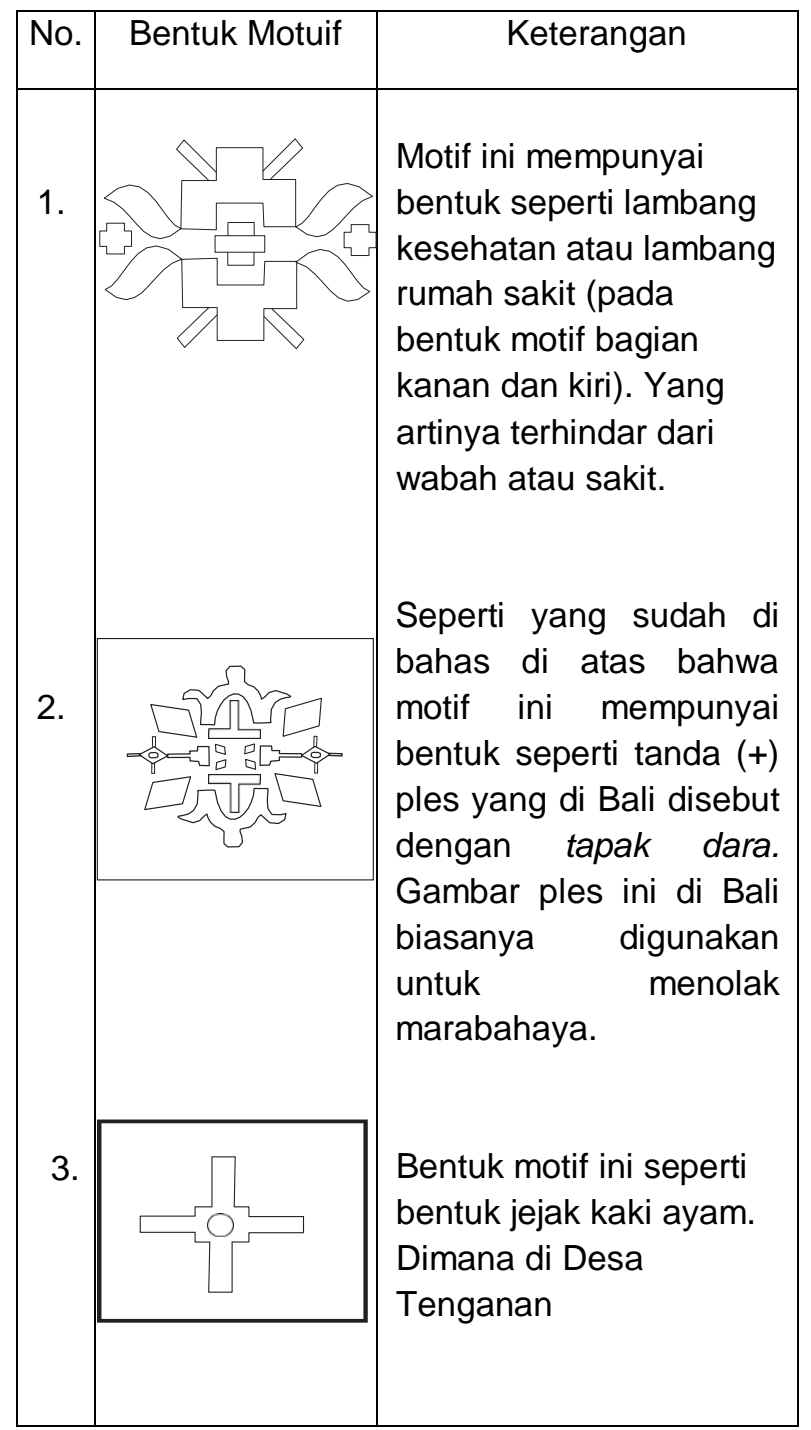

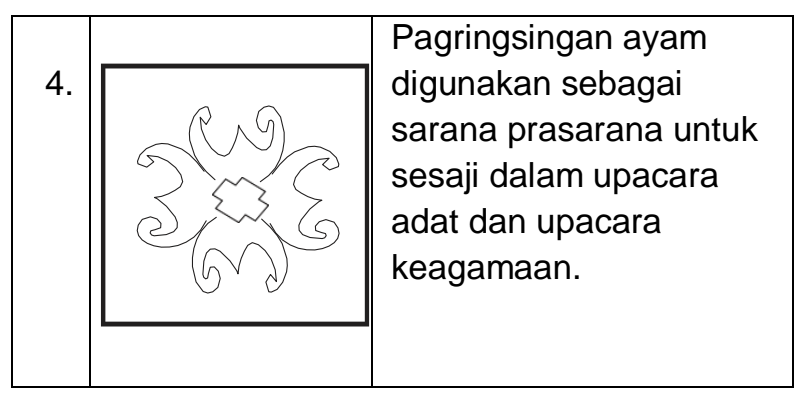

\section{Dingding Sigading}

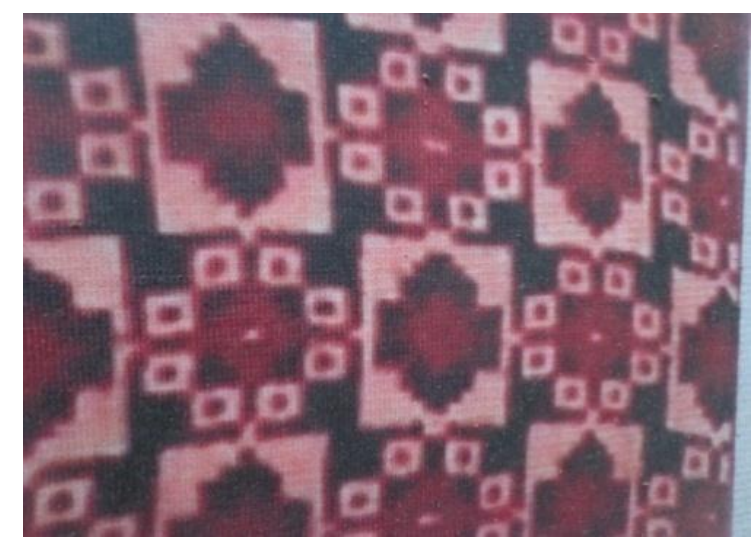

Gambar 2.34. Motif Tenun Gringsing Dingding Sigading

Gambar pecahan motif Tenun Gringsing Dingding Sigading

\begin{tabular}{|l|l|l|}
\hline No. & Bentuk Motif & \multicolumn{1}{c|}{ Keterangan } \\
\hline 1. & $\begin{array}{l}\text { Motif ini mempunyai } \\
\text { bentuk seperti rumah } \\
\text { tawon yang } \\
\text { menggambarkan } \\
\text { Keberaturan masyarakat } \\
\text { Tenganan Pagringsingan. }\end{array}$ & $\begin{array}{l}\text { Bentuk motif ini juga } \\
\text { merupakan } \\
\text { perkembangan dari tanda } \\
\text { ples (+) yang mempunyai } \\
\text { makna sebagai lambang } \\
\text { jalanya matahari }\end{array}$ \\
\hline 2 & &
\end{tabular}




\section{Dingding Ai}

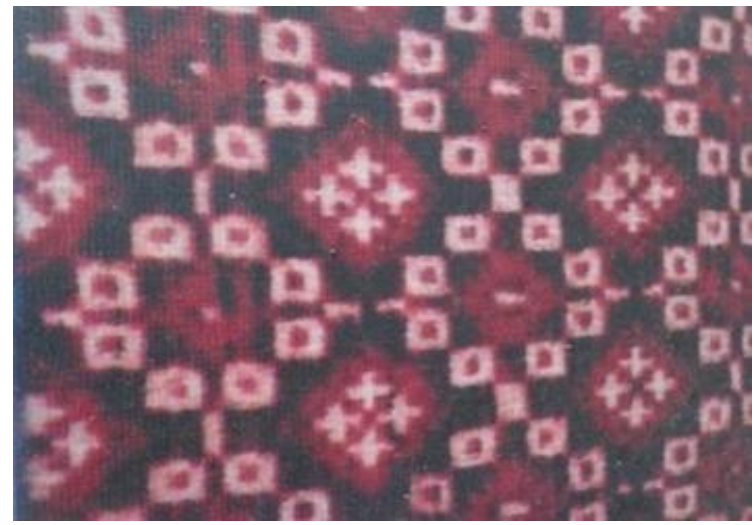

Gambar 2.35. Motif Tenun Gringsing Dingding $\mathrm{Ai}$

Gambar pecahan motif Tenun Gringsing Dingding Ai

\begin{tabular}{|l|l|}
\hline No. & \multicolumn{1}{c|}{ Keterangan } \\
Motif ini mempunyai \\
bentuk seperti rumah \\
tawon yang \\
menggambarkan \\
keberaturan masyarakat \\
Tenganan
\end{tabular}

\section{Sitan Pegeg}

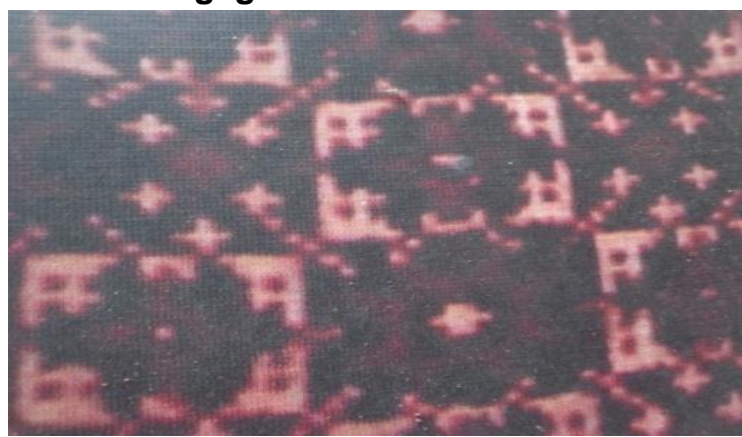

Gambar 2.36. Motif Tenun Gringsing Sitan Pegeg

Gambar pecahan motif Tenun Gringsing Sitan Pegeg

\begin{tabular}{|l|l|l|}
\hline No. & Gambar Motif & \multicolumn{2}{|c|}{ Keterangan } \\
\hline 1. & $\begin{array}{l}\text { Motif ini mempunyai } \\
\text { bentuk gerbang yang } \\
\text { menggambarkan } \\
\text { keberaturan masyarakat } \\
\text { Tenganan Pagringsingan. }\end{array}$ \\
\cline { 2 - 3 } & & $\begin{array}{l}\text { Motif ini mempunyai } \\
\text { bentuk seperti bintang } \\
\text { yang mempunyai empat } \\
\text { sudut yang } \\
\text { melambangkan empat } \\
\text { arah mata angin yaitu } \\
\text { selatan, barat, utara, dan } \\
\text { timur. Serta tanda ples } \\
\text { yang artinya terhindar } \\
\text { dari wabah. }\end{array}$ \\
\hline & &
\end{tabular}

\section{Teteledan}

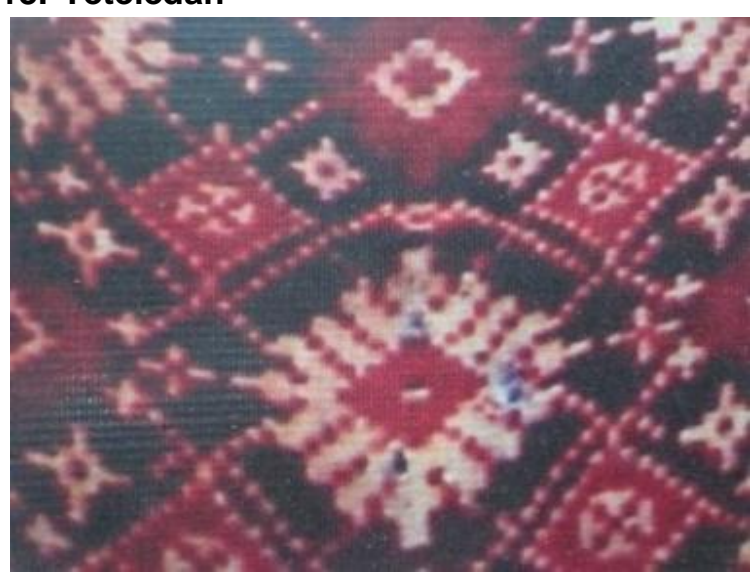

Gambar 2.37. Kain Tenun Gringsing Teteledan 
Gambar pecahan motif Kain Tenun Gringsing Teteledan

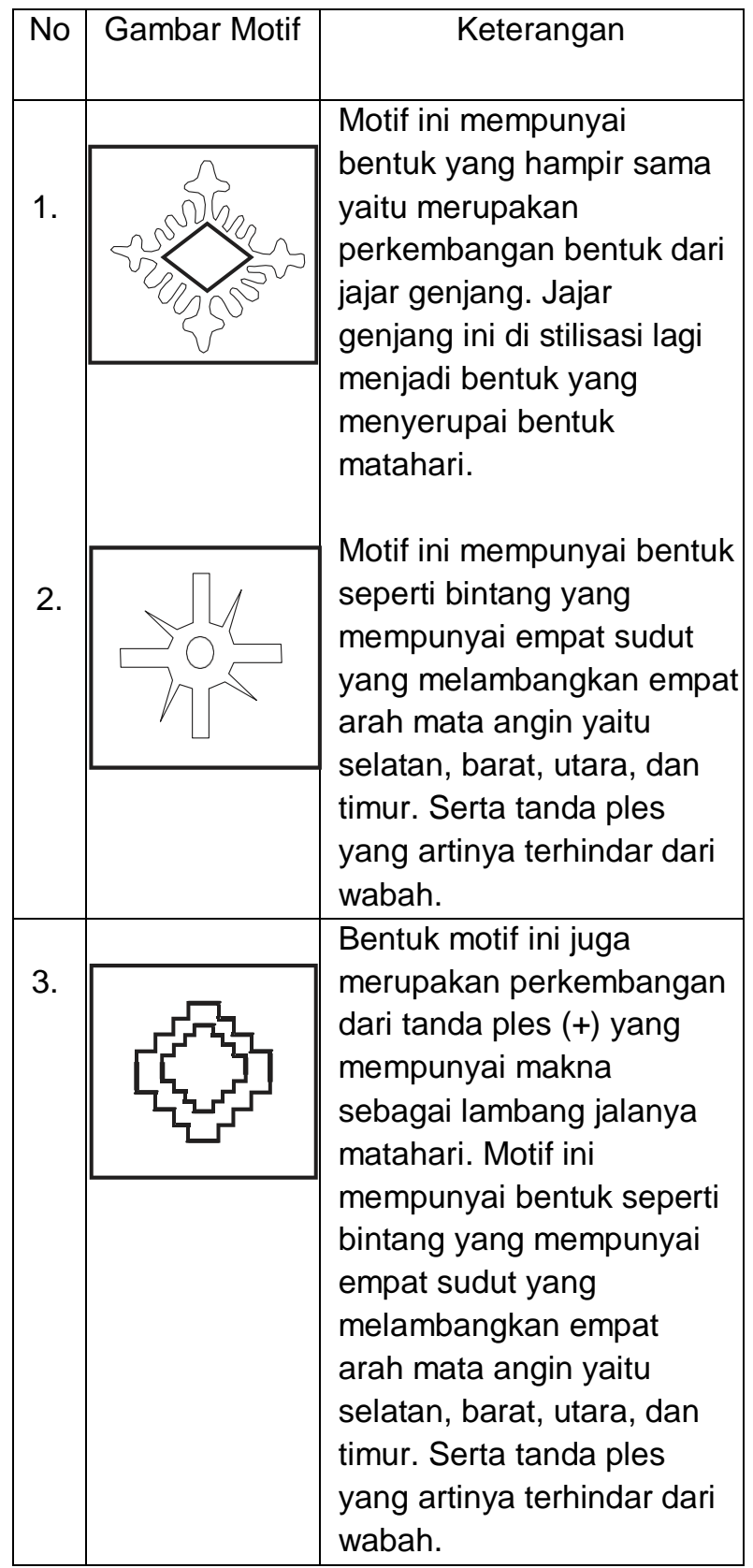

14. Senan Empeg

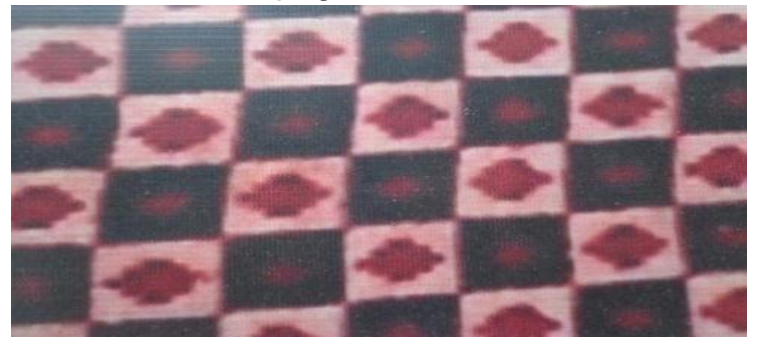

Gambar 2.38. Motif Kain Tenun Gringsing Senan Empeg
Gambar pecahan motif Kain Tenun Gringsing Senan Empeg

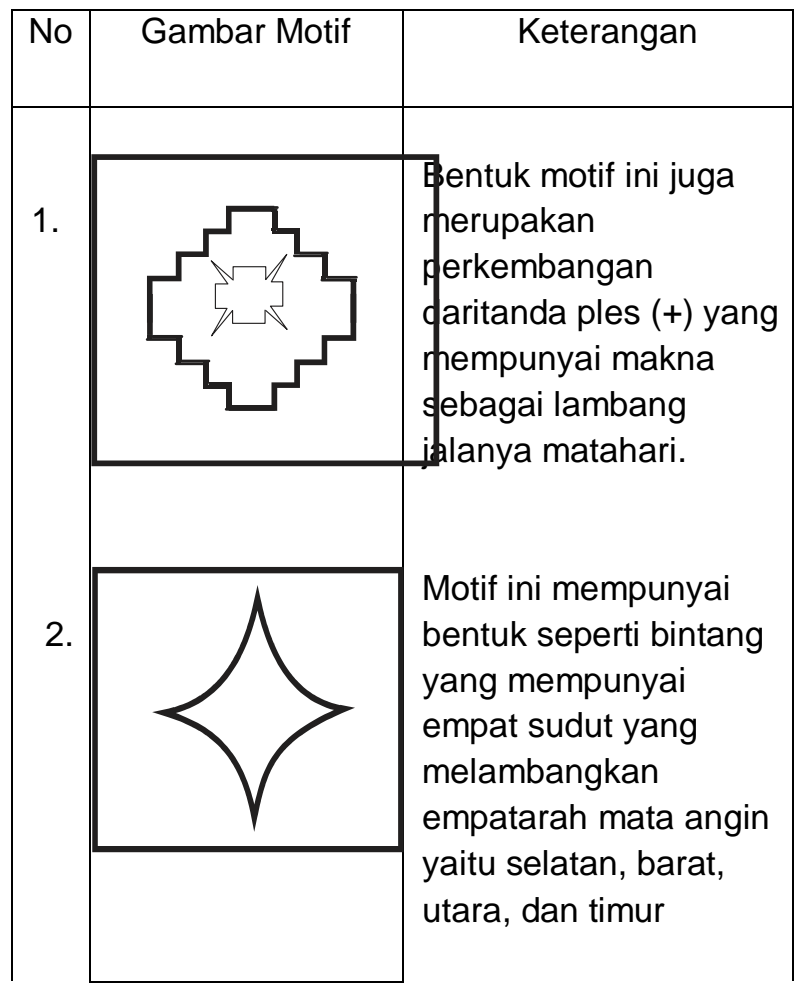

Dari beberapa Kain Gringsing seperti tersebut di atas Kain Gringsing ini hanya mempunyai tiga warna bukan berarti masyarakat Desa Tenganan Pagringsingan tidak bisa membuat warna lain selain warna merah, hitam, dan putih. Akan tetapi masing-masing warna yang dihasilkan ini mempunyai makna.

Ketiga warna ini adalah simbol dari tri sakti (dewa yang diyakini oleh masyarakat Tenganan Pagringsingan mempunyai tiga kekuatan). Dewa Brahma ini adalah dewa pencipta yang disimbolkan dengan warna merah. Dewa Wisnu adalah dewa pemelihara yang disimbolkan dengan warna hitam atau biru tua. Dan Dewa Siwa adalah dewa pelebur yang disimbolkan dengan warna putih. Karena kita hidup di dunia ini diciptakan, kemudian kita hidup dipelihara, dan mati atau dilebur. Tri sakti ini yang mendasari terciptanya Kain Gringsing.

Tenun yang dihasilkan oleh masyarakat tenganan mempunyai beberapa fungsi antara lain sebagai berikut:

a. Di gunakan untuk upacara adat dan upacara keagamaan, akan tetapi ada 
ketentuan-ketentuan yang harus di taati dan ada doanya.

b. Digunakan untuk pakaian pengantin sebagai pakaian adat masyarakat Tenganan Pagringsingan.

c. Digunakan sebagai sarana untuk misata atau pengobatan.

Secara garis besar fungsi tenun untuk seluruh masyarakat Tenganan Pagringsingan seperti disebut di atas. Namun dengan perkembangan jaman kain tenun tersebut juga telah berfungsi sebagai sumber ekonomi, yaitu dengan cara diperjual-belikan secara luas.

Jika dilihat dari realitas kehidupan masyarakat Tenganan, terlihat adanya peri laku yang selalu bersinggungan dengan hal-hal yang menyangkut keindahan. Kain Gringsing menjadi keharusan untuk dipakai oleh perempuan dan pemuda Tenganan, maka keindahan telah menjadi bagian gaya berpakaian. Demikian pula dengan keberadaan musik, tarian, dan peristiwa mekare-kare yang menawarkan sebuah kerangka keindahan dalam sebuah upacara yang di dalamnya mengandung kekuatan magis. Keindahan tersebut dengan sendirinya memberikan beragam makna di dalamnya.

Praktik-praktik magis dan religius bergantung pada unsur-unsur seperti status resmi yang baku atau anugerah Tuhan, dan dihargai tinggi dalam tradisinya untuk menjaga tatanan. Serta menunjuk pemakaian jimat dan hiasan magis lain untuk menangkal kekuatankekuatan spiritual dan magis (Barnard,1996: 95). Sesuai dengan mitos yang hidup dalam tatanan masyarakat Tenganan Pagringsingan kain gringsing juga dipercaya sebagai kain yang berfungsi sebagai penolak bala bagi pemakainya.

Meskipun bentuk dan warna Tenun Gringsing terbilang sangat sederhana, akan tetapi Tenun Gringsing ini mempunyai nilai estetis yang layak untuk dikaji. Estetika Tenun Gringsing tidak bersifat subyektif yaitu dengan menempatkan keindahan pada saat mata memandang namun Tenun Gringsing ini bersifat objektif yaitu dengan menempatkan keindahan pada benda yang dilihat.

Dalam Tenun Gringsing ini warna yang digunakan mempunyai bobot atau isi pesan yang ingin disampaikan kepada pemakainya. Hal ini sangatlah terlihat jelas pada selembar Tenun
Gringsing yang hanya memiliki tiga warna yaitu warna merah, hitam/ biru tua, dan putih. Warna yang digunakan ini adalah warna pilihan yang mempunyai arti dan bukan berarti masyarakat tenganan tidak bisa membuat warna selain tiga warna tersebut.

Makna dari warna yang digunakan ini adalah sebagai lambang kehidupan. Mereka mengartikan ketiga warna ini adalah lambang trisakti atau lambang tiga kekuatan dewa. Dalam masing-masing warna ini memiliki peranan penting bagi masyarakat tenganan pagringsingan yaitu bahwa ketika ada di bumi ini di ciptakan, kemudian hidup dipelihara, dan meninggal di lebur. Di sini ada perputaran dalam kehidupan dan berlangsung selama dunia ini masih ada.

\section{Karakteristik Tenun Gringsing}

Tenun Gringsing pada dasarnya memilik karakter "Spiritual" tergambar dari komposisi warna, makna simbol, hingga proses pembuatannya. Nilai spiritual pada Tenun Gringsing ini sangat mewakili berbagai aspek yang menjadi keyakinan pada masyarakat Desa Tenganan Pagringsingan. Tanpa menafikan nilainilai estetis, karya tenun gringsing sangat kuat dalam mengeja-wantahkan unsur-unsur budaya yang telah dijaga turun-temurun.

Disamping itu, Tenun Gringsing yang kuat dalam penggambaran spiritualnya tidak hanya berkarakter vertikal melainkan juga horisontal, kebersamaan menjadi penopang utama dalam kehidudan sosial bermasyarakat. Pengaturan hak-hak dan kewajiban antar penduduk tertata begitu harmoni. "Duduk sama rendah berdiri sama tinggi" keseimbangan antar sesama masyarakat yang menempati desa ini pun tergambar dari karya Tenun Gringsing. Kecintaan terhadap alam, tumbuhan, dan hewan. Pada dasarnya seluruh rangkaian kehidupan yang terjadi di desa Tenganan Pagringsingan tidak terlepas dari nilai-nilia spititual. Tiga warna dasar yang selalu menjadi corak utama seolah menegaskan apa yang hendak disampaikan. Tiga dewa maha tinggi dalam keyakinan umat beragama Hindu menjadi unsur dominan.

Penghayatan makna nilai spiritual inilah yang mendorong masyarakat Desa Tenganan Pagringsingan dengan Tenun Gringsingnya yang senantiasa berlaku adil terhadap sesama. Tidak 
hanya dalam bentuk visual, tetapi tenun gringsing memiliki nilai filosofi yang sangat mendalam. Hampir disetiap bentuk perayaan atau kegiatan masyarakat adat setempat tidak akan lepas dari kain ini. Setiap kain hasil olahan pengrajin yang menghasilkan Tenun Gringsing akan digunakan dalam kesempatan yang berbeda-beda. Inilah yang disebut nilai "spiritual" dalam tenun Gringsing. Landasan spiritual yang terjaga sejak jaman nenek moyang hingga saat inilah yang pada akhirnya menjadikan Desa Tenganan Pagringsingan tersohor dengan hasil karya tenunnya.

Tenun Gringsing terus lestari. Kekuatan batin yang terejawantahkan dalam bentuk visual selalu menjadi daya tarik yang berbeda bagi siapa saja yang menikmati hasil karyanya.

Karakter spiritual yang sangat kuat tergambar dalam corak Tenun Grinsing turut menjaga adat-istiadat dan budaya asli yang masih terjaga hingga saat ini. Kemajuan jaman yang pesat tidak mampu menggoyahkan apa yang telah menjadi kepercayaan dan keyakinan masyarakat Desa Tenganan Pagringsingan Karangasem Bali.

\section{SIMPULAN}

Tenun Gringsing yang dibuat oleh masyarakat Desa Tenganan Pagringsingan Karangasem Bali bukan sekedar kain tenun biasa. Tenun Gringsing merepresentasikan tata nilai kehidupan masyarakat Desa Tenganan Pagringsingan Karangasem Bali.

Tenun Gringsing menggambarkan tentang sistem keseimbangan yaitu tentang hubungan manusia dengan manusia, manusia dengan alam, dan manusia dengan Tuhan. Dewa Indra yang selalu dipuja oleh masyarakat Tenganan Pagringsingan di hormati dengan sebuah ritus perang pandan. Rasa sakit seolah sirna oleh gringsing yang selalu membalut tubuh. Gringsing dipercaya dapat terhindar dari penyakit. Lebih kompleks lagi Gringsing adalah penolak mara bahaya. Masyarakat Bali Aga percaya Gringsing memiliki kekuatan magis yang melindungi mereka dari sakit dan kekuatan jahat. Tenganan adalah cerita tentang masyarakat yang terus berjuang mempertahankan identitas yang mereka banggakan sebagai orang Bali asli.
Karena Gringsing begitu penting dalam kehidupan masyarakat Tenganan, kain ini seperti cermin perjalanan kehidupan masyarakat setempat. Sampai sekarang masih ada yang mengira warna merah Gringsing berasal dari darah. Mungkin Kain Gringsing merah yang digunakan para gadis dalam perang pandan menjadi penanda betapa beratnya pertarungan sang satria.

Kepercayaan mengenai kekuatan magis kain itu lalu menghasilkan mitos sendiri. Keunikan Kain Gringsing inilah, antara lain, yang menjadikan Tenganan Pegringsingan memiliki nama atau dikenal di dunia pariwisata. Kemasyuran ini bertahan berkat praktik tradisionalisasi diri. Lihatlah misalnya, bagaimana Tenganan sanggup menghadirkan turis setiap harinya karena sejumlah praktik kehidupan dan berbagai benda tradisi selalu dihidupkan.

Semua telah tertata dalam aturan keseimbangan yang di sebut awing-awing. Jalinan serasi antara mitos dan estetika, semua direpresentasikan dengan begitu indahnya di Tenganan Pagringsingan Karangasem Bali lewat Tenun Gringsing. Adat istiadat harus kita junjung tinggi karena merupakan citra diri juga melambangkan harga diri akan suatu negeri. Adat istiadat jangan sampai hilang agar orang lain tau dari mana kita berasal.

Bali Pulau Dewata menampilkan berbagai macam keindahan yang masih sangat kuat memegang tradisi di dalam kehidupan seharihari. Seperti upacara adat dan upacara keagamaan ini tidak bisa dipisahkan dengan pakaian tradisionalnya yang sangat disakralkan yaitu kain Tenun Gringsing. Kehadiran Gringsing tak bisa dilihat hanya pada sebuah lembaran kain tetapi nilai kebudayaan yang terdapat di dalam Tenun Gringsing.

Unsur keseimbangan dalam hidup agar manusia menjaga tiga elemen yang telah di gambarkan di dalam tenun gringsing yaitu api, air, dan udara yang identik dengan warna merah, hitam, dan putih. Orang Tenganan Pagringsingan Karangasem Bali mempunyai aturan tentang cara mengelola lingkunganya termasuk hutan bercampur kebun yang mengelilingi desa. Sehingga sampai saat ini hutan Desa Tenganan Pagringsingan Karangasem Bali masih tetap terjaga dengan baik untuk keseimbangan dan 
keberlanjutanya.

Kain Gringsing ini menggambarkan tentang sistem keseimbangan yaitu tentang hubungan manusia dengan manusia, manusia dengan alam, dan manusia dengan Tuhan. Konsep tenun gringsing yang memadukan berbagai macam inisiatif, baik yang bersifat vertikal dan horisontal mampu memberikan warna bagi seluruh kehidupan bermasyarakat. Pada kususnya masyarakat Tenganan Pagringsingan Karangasem Bali dan masyarakat Indonesia serta masyarakat Internasional pada umumnya. Nilai-nilai yang terkandung di dalam Tenun Gringsing tidak akan tergerus jaman.

Hubungan vertikal dan horisontal sangat kental dalam nilai filosofi Tenun Gringsing. Keseimbangan keduanya mampu memberikan harmonisasi bagi keberlangsungan kehidupan alam semesta. Warisan yang adiluhung seperti Tenun Gringsing seyogyanya menjadi perhatian khusus bagi pemerintah untuk melestarikanya. Peranan dari pemangku kebijakan menjadi hal terpenting disamping masyarakat adat sendiri. Meski telah mendapatkan perhatian dari pemerintah, seiring dengan perkembangan jaman sudah semestinya semua hal yang berkaitan dengan Tenun Gringsing ini harus selalu menjadi perhatian kusus.

\section{DAFTAR PUSTAKA}

Adi Kusrianto, 2020, Sarung Tenun Indonesia Ensiklopedia-Filosofi-Sampai Industri,
Penerbit Other.

Ani Yudhoyono, 2012, Tenunku, Gramedia Pustaka Utama.

Debbie Suryawan,Stephanus Hamy, 2009, Chie Mengolah Wastra Indonesia : Tenun NTT (SC), Gramedia Pustaka Utama,

Kompasiana, 2019, Mengenal Kain GringsingKain Khas Bali Yang Sarat Filosofis, https://www.kompasiana.com/fery87654/ 5d98e31b0d82306f6132df92/kaingringsing-khas-bali-kain-yang-penuhfilosofi

Siska Sumartono, 2012, Trendi Dengan Busana Tenun-Kreasi Busana Tenun Nusantara, Niaga Swadaya (Group Penebar Swadaya).

Suwati Kartiwa, 2007, Ragam Kain Tradisional Indonesia : Tenun Ikat, Gramedia Pustaka Utama.

Wayan Suadnyana, 2015, Tenganan Pagringsingan Bali-Keunikan Desa Kerajinan Kain Gringsing, https:// www.rentalmobilbali.net/tenganan/

Wikipedia, Kain Gringsing, https://id. wikipedia.org/wiki/Kain_gringsing. 